\title{
Invited review: Learning from the future-A vision for dairy farms and cows in 2067
}

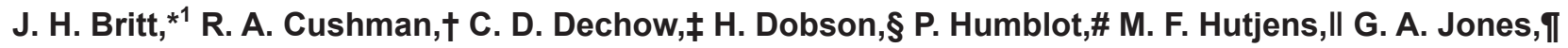 \\ P. S. Ruegg, ${ }^{* *}$ I. M. Sheldon, †† and J. S. Stevenson $\ddagger$ \\ *Department of Animal Science, North Carolina State University, Raleigh 27695-7621 \\ †USDA Agricultural Research Service, US Meat Animal Research Center, Clay Center, NE 68933 \\ †Department of Animal Science, Pennsylvania State University, University Park 16802 \\ $\S S c h o o l$ of Veterinary Science, University of Liverpool, Neston, United Kingdom CH64 7TE \\ \#Department of Clinical Sciences, Swedish University of Agricultural Sciences, Uppsala, 750 07, Sweden \\ IIDepartment of Animal Sciences, University of Illinois, Urbana 61801 \\ TCentral Sands Dairy, De Pere, WI 54115-9603 \\ ${ }^{* *}$ Department of Animal Science, Michigan State University, East Lansing 48824-1225 \\ ††Swansea University Medical School, Swansea, Wales, United Kingdom SA2 8PP \\ $\ddagger \ddagger D$ epartment of Animal Sciences and Industry, Kansas State University, Manhattan 66506-0201
}

\section{ABSTRACT}

The world's population will reach 10.4 billion in 2067 with $81 \%$ residing in Africa or Asia. Arable land available for food production will decrease to 0.15 ha per person. Temperature will increase in tropical and temperate zones, especially in the Northern Hemisphere, and this will push growing seasons and dairy farming away from arid areas and into more northern latitudes. Dairy consumption will increase because it provides essential nutrients more efficiently than many other agricultural systems. Dairy farming will become modernized in developing countries and milk production per cow will increase, doubling in countries with advanced dairying systems. Profitability of dairy farms will be the key to their sustainability. Genetic improvements will include emphasis on the coding genome and associated noncoding epigenome of cattle, and on microbiomes of dairy cattle and farmsteads. Farm sizes will increase and there will be greater lateral integration of housing and management of dairy cattle of different ages and production stages. Integrated sensors, robotics, and automation will replace much of the manual labor on farms. Managing the epigenome and microbiome will become part of routine herd management. Innovations in dairy facilities will improve the health of cows and permit expression of natural behaviors. Herds will be viewed as superorganisms, and studies of herds as observational units will lead to improvements in productiv-

Received October 19, 2017.

Accepted January 23, 2018

${ }^{1}$ Corresponding author: jackhbritt@gmail.com ity, health, and well-being of dairy cattle, and improve the agroecology and sustainability of dairy farms. Dairy farmers in 2067 will meet the world's needs for essential nutrients by adopting technologies and practices that provide improved cow health and longevity, profitable dairy farms, and sustainable agriculture.

Key words: dairy, future, technology, management

\section{INTRODUCTION}

Demand for dairy products and technologies will grow during the next 50 yr for 2 reasons. First, increased per capita income worldwide will boost demand for dairy and other food products from animals, and these products increasingly will provide essential nutrients in developing countries. The Food and Agriculture Organization (FAO) of the United Nations states: "Even small amounts of animal source foods can improve the nutritional status of low-income households. Meat, milk and eggs provide proteins with a wide range of amino acids as well as micronutrients such as iron, zinc, vitamin $\mathrm{A}$, vitamin $\mathrm{B}_{12}$, and calcium, in which many malnourished people are deficient" (Kourous, 2011). Second, dairy products efficiently meet nutritional requirements of humans from the standpoint of farming practices. Production of milk uses less land to produce $1 \mathrm{~g}$ of readily edible protein than production of other livestock or poultry products and some plant products (Figure 1; Clark and Tillman, 2017; Roser and Ritchie, 2017). Dairy-based diets are superior to vegan-, eggand omnivore-based diets for maximizing capacity of croplands to feed the greatest number of people while adhering to recommended agronomic practices for various classes of lands (Peters et al., 2016). The advantage of dairy- and egg-based diets over vegan-based diets is 
attributable to the essential amino acids and micronutrients from dairy- and egg-based diets that are missing in appropriate ratios in typical plant-based foods.

To supply increased demand for dairy products in the decades ahead, there must be a sustainable balance between products produced within country and imports. This provides opportunities for developed and developing exporting countries to provide dairy products as well as dairy equipment and technologies to expand dairy farming in countries where suitable land resources exist (Gerosa and Skoet, 2012).

As demand for dairy products increases, it is important to understand global dairy production today and how it may change during the decades ahead. We have been engaged informally for more than $2 \mathrm{yr}$ with a specific focus on dairy cows and farms in 2067-primarily in developed countries with advanced dairy farm industries and technologies. In this forward-looking commentary, we first focus on global projections for population, arable land, and climate change, and on current dairy production in developed and developing countries. Then, we transition to describing changes that will occur in dairy cows, farms, technologies, and practices by 2067 .

\section{GLOBAL CHANGES THAT WILL AFFECT DAIRY PRODUCTION BY 2067}

\section{Population}

The United Nations estimates that our world's population will grow from 7.6 to 10.5 billion between 2017 and 2067 (United Nations, 2017). This projection represents the median variant, between high (12.6 billion) and low (8.6 billion) variants. Asia and Africa will account for $93 \%$ of this growth (Figure 2). Latin America and the Caribbean, North America, and Oceania will grow modestly, whereas Europe will decline in population. Half of the world's population in 2067 will live in 10 countries, ranked by population: India, China, Nigeria, United States, Pakistan, Indonesia, Democratic Republic of the Congo, Ethiopia, Brazil, and Bangladesh. Population density will increase by $162 \%$ in Africa and by between 16 and $46 \%$ in most other regions and decline 7\% in Europe by 2067 (inset, Figure 2), resulting in greater disparities in amount of arable land per capita among regions.

\section{Arable Land}

Growth in populations in Asia and Africa will put additional limits on amount of arable land per capita for food and feed production (World Bank, 2017). Cur- rently, there is a 6-fold difference in amount of arable land (ha per person) among regions of the world (North America, 0.59; Europe and Central Asia, 0.38; Latin America and Caribbean, 0.28; Sub-Saharan Africa, 0.22; World, 0.20; Middle East and North Africa, 0.13, and East Asia and Pacific, 0.10. By 2067, there will be an estimated 0.15 ha of arable land per person worldwide (Alexandratos and Bruinsma, 2012).

Increased use of permanent grasslands and byproduct feeds for milk production will decrease pressure on arable land (Gill et al., 2010; Wilkinson, 2011) and improve food security in countries that have lands for permanent grazing. Countries with less arable land per capita will increasingly use their available land to produce human food rather than livestock feed. Some existing permanent grasslands will be converted to arable land in developing countries, which will reduce land for grazing by dairy cattle.

Some countries, such as China, are pursuing strategies in which investments in dairy production are focused on acquisition of dairy farms and processing facilities offshore in countries with more arable land per capita. Dairy farming and processing facilities in these countries will produce dairy products for import into China (Australia Plus, 2017).

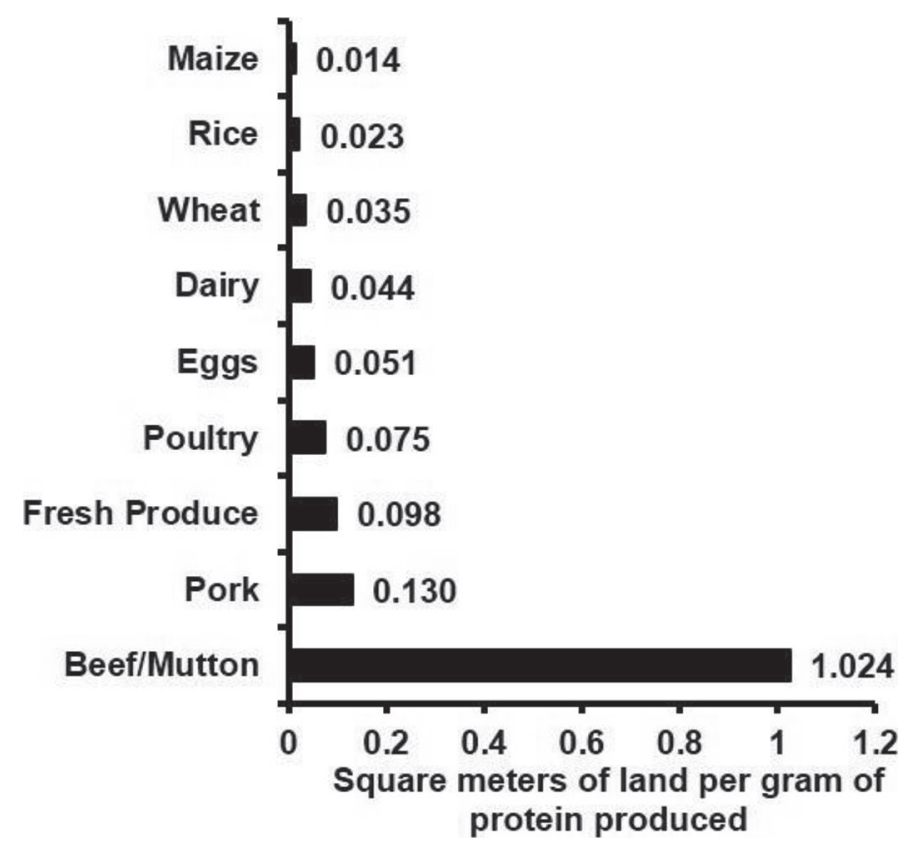

Figure 1. Square meters of land required to produce $1 \mathrm{~g}$ of edible protein from various crops or production systems. Data from Clark and Tillman (2017) and graph modified from Roser and Ritchie (2017) under a Creative Commons CC BY-SA 2.0 license (https:// creativecommons.org/licenses/by-sa/2.0/). 


\section{Climate Change}

Changes in climate during the next 50 yr will affect where dairy farms and cattle are located and focus more attention on types of cattle that are adaptable to various regions. Climate in the Northern Hemisphere is particularly important because $81 \%$ of the world's population lives north of the equator (Lutz, 2012). Similarly, $86 \%$ of world's milk from dairy cattle is produced north of the equator (FAOSTAT, 2017).

Global temperature has increased steadily for several decades (Figure 3). This trend has been particularly consistent during the last 5 decades and most forecasts expect it to continue. Forecasts for changes in climate in the Northern Hemisphere include warmer temperatures year-round, greater variation in precipitation, and longer growing seasons toward the polar latitudes. This forecast is also true for the Southern Hemisphere but it is dampened by tempering effects of the oceans. It is predicted that the future climate will have longer periods of both drought and excess rainfall, with more severe weather incidents.

The warming climate could add arable land to produce food and feed crops in northern regions of North America, Europe, and Asia; however, some of this could be offset by losses of arable land associated with less rainfall and less water for irrigation of crops in other areas of each region. Changes in climate will cause shifts in locations of dairy cows and farms. For example, in the United States, approximately $42 \%$ of milk produced currently originates in states that are expected to have severe water shortages by 2067 (Figure 4). A significant portion of dairy cows in these areas will be relocated to areas with more sustainable water supplies and adequate growing seasons. Areas in North America that are most suitable for dairy expansion are in the Upper Midwest and Great Lakes regions and the central provinces of Canada. These areas are forecast to have adequate water resources and longer growing seasons in 2067. Similarly, Russia will have more land suitable for crop production in its northern latitudes and dairy cows will move into these areas.

\section{DAIRY CONSUMPTION AND PRODUCTION}

Worldwide, annual consumption of dairy products (fresh milk equivalent basis) currently averages about $87 \mathrm{~kg}$ per person and is expected to increase to 119 kg per person worldwide by 2067 , based on extrapola-

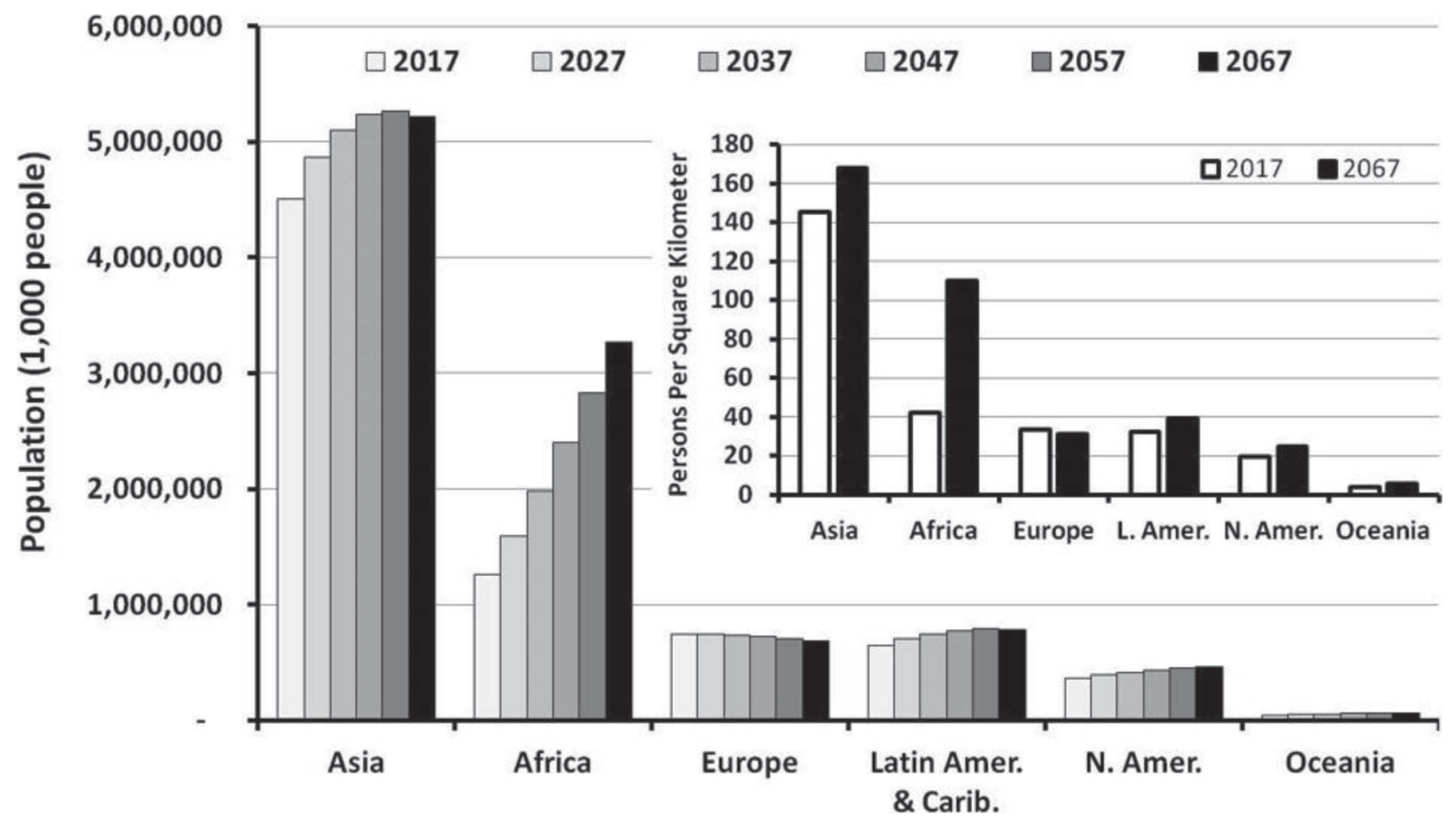

Figure 2. Estimated population of world's regions from 2017 to 2067 and estimated population density for 2017 and 2067 . Raw population data downloaded from United Nations (2017). Inset shows population density (persons per $\mathrm{km}^{2}$ ) for each region. L. Amer. = Latin America; N. Amer. = North America; Carib. = Caribbean. 


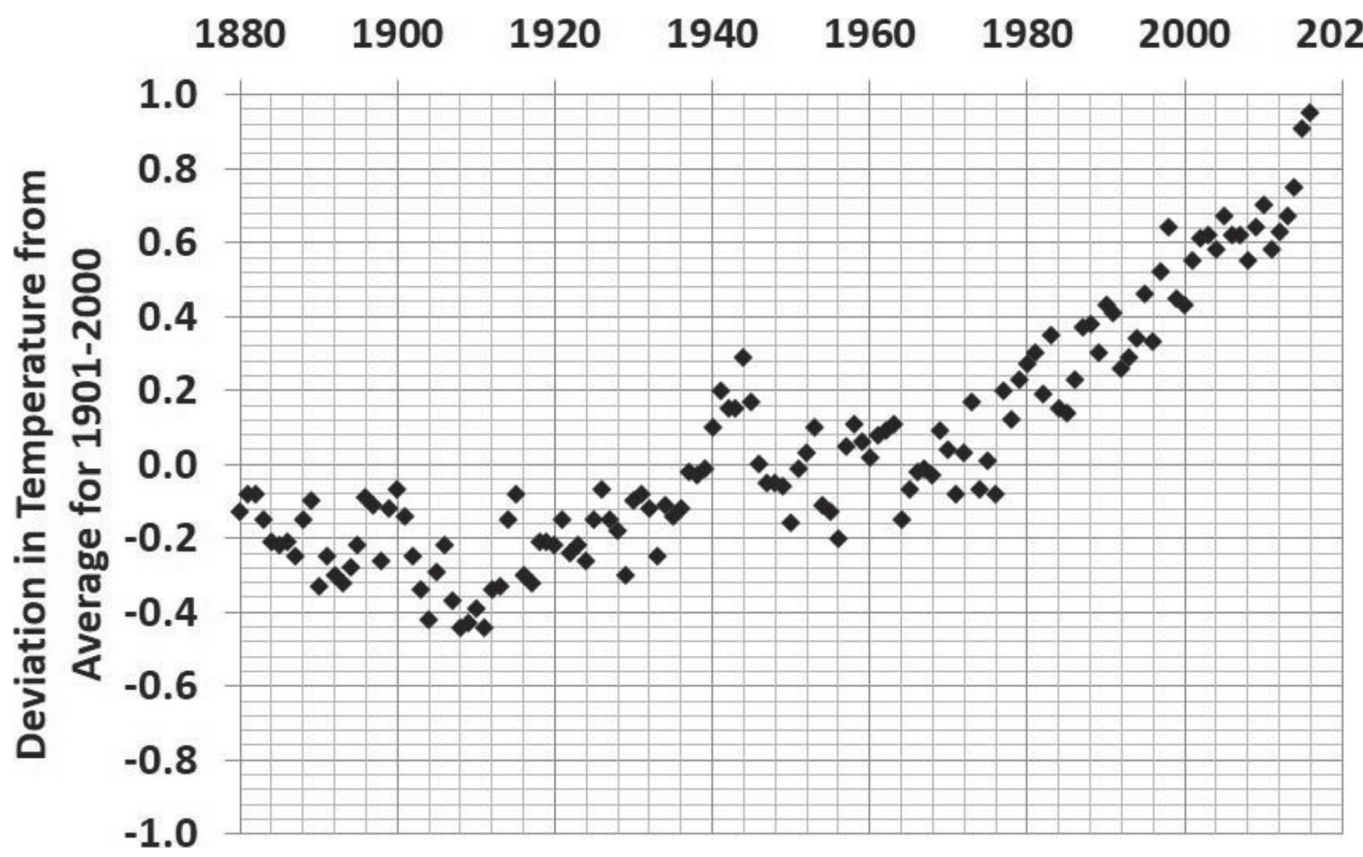

Figure 3. Deviations in average global temperature from average global temperature for 1901 to 2000. Source of data: NOAA National Centers for Environmental Information, Climate at a Glance: Global Time Series (published July 2017, retrieved Jul. 27, 2017, from http:// www.ncdc.noaa.gov/cag/).

tions from Alexandratos and Bruinsma (2012). These estimates do not include butter, which is included as an animal fat in the food classification system used by the FAO.

Migration from rural to urban areas typically leads to increased personal income, which leads to increased consumption of dairy products in developing countries such as India (Bowen et al., 2011); therefore, a substantial increase in demand for dairy products is expected in countries of Africa and Asia that are experiencing robust growth in urban areas. Dairy intakes in developed countries are around $225 \mathrm{~kg} / \mathrm{yr}$ per person and do not differ between rural and urban areas (Davis et al., 2008); therefore, increased urbanization in these countries will not influence per capita intake.

Increased consumption of dairy products coupled with increased growth in population translates into a need for approximately 600 billion kilograms more milk in 2067 than is produced today. According to FAO, dairy cows produce $82.4 \%$ of the world's milk, followed by buffalo (13.6\%), goats $(2.3 \%)$, sheep (1.3\%), and camels (0.4\%). In 2014, an estimated 274 million dairy cows dotted the globe (FAOSTAT, 2017). To produce the estimated 600 billion kilograms of additional milk needed by 2067, an average dairy cow on the globe would need to double its annual yield from 2,405 to 4,531 kg. This seems unlikely to occur because many countries with lowest annual production per cow have the most cows (Figure 5). Countries that are modern- izing their dairy farming and processing sectors seem positioned to meet the future demand; however, farms of the future must be profitable to be sustainable, so this presents challenges to the industry.

\section{Modernization of Dairy Production}

Urbanization and globalization have driven the modernization (industrialization) of agriculture and the dairy industry worldwide. As people move from farms and rural villages to urban centers, agriculture adopts mechanization and automation to produce food products for urban consumers. Urbanization has driven international trade because of increased earnings of urban dwellers.

Dairy farm modernization leads to implementation of sanitation and quality standards and adoption of standardized handling equipment such as stainless-steel containers on the farm. Larger and more specialized dairy processing plants impose requirements on milk producers to increase quality and volume. Overall, modernization of dairy farms and specialization of processing reduces costs for dairy products for consumers in urban areas (Nicholson et al., 2011).

\section{Recent Industrialization Example from Zambia}

It is informative to learn from the modernization of the dairy industry in Zambia over the last $25 \mathrm{yr}$ (Neven et al., 2017). Beginning in 1991, the industry 


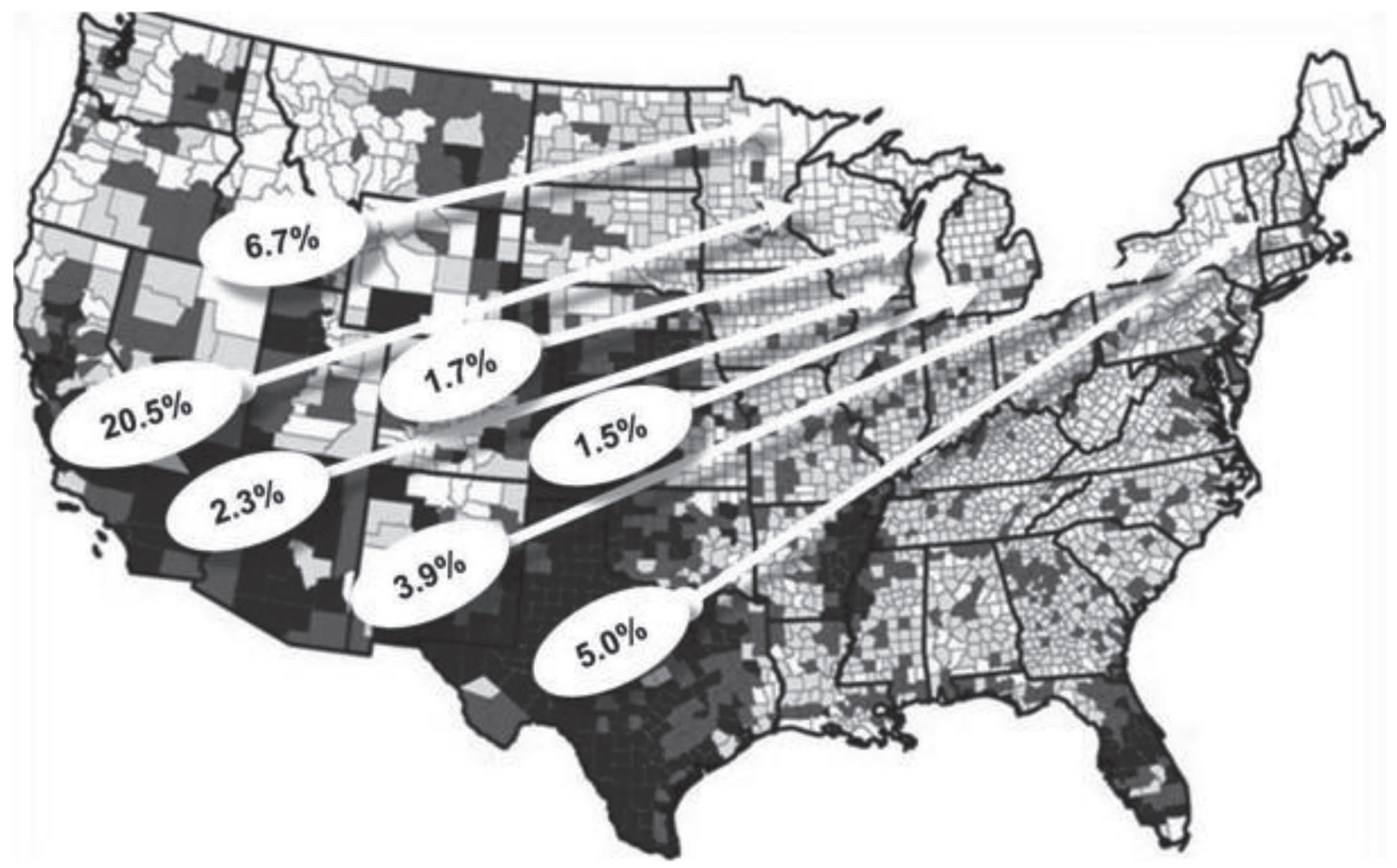

Figure 4. Projected relocation of dairy farming from US regions with shortages of water to North American regions with adequate water during the next 50 yr. Darker shaded areas will have less sustainable water supplies with current projections of climate change. Percentage in the base of each arrow represents estimated percentage of US milk produced currently in that state. Original underlying map converted to black and white and used with permission (Roy et al., 2012).

was privatized and began with 3 types of production: (1) milk produced for the family or household; (2) milk produced by smallholders for sale locally to individuals, local spot markets, or collection centers (emerging producers); and (3) milk produced for sale directly to commercial processing enterprises (industrialized farms). This latter group included herds with about 50 cows or more. Types of cropping and feeding systems overlapped among these 3 dairy farm settings in Zambia. Grazing was a primary source of feed but even household units purchased fodder and grains to feed cows year-round or during certain seasons.

Common obstacles hindered transition among stages (household, smallholder, and industrial). To move from household to smallholder required improved sanitation, utilization of stainless-steel milk pails, and compliance with minor milk quality standards. Investments in equipment in this transition were modest, but requirements for adhering to sanitation and quality standards challenged traditional households and smallholders.
The greatest challenge to moving into the industrial category was the cost of equipment and facilities to sell directly to milk processors. This required milking facilities with concrete floors and on-farm refrigeration of the milk. Sanitation standards were also increased so the milk would meet grade-A standards. Moving to the industrial level required access to more land for grazing and feed production. Many producers dropped out at the smallholder stage and some dropped out after reaching the industrial stage.

Milk processing plants in Zambia paid higher prices to dairy producers in their country than prices paid at the same time in North America and Europe, and it was more profitable for processing plants to import milk powder from international suppliers than to produce products within the country. Nevertheless, the dairy industry in Zambia continues to grow in part because of a focus on food security. This recent experience in Zambia reflects historical maturation of the dairy industry in developed countries. 


\section{Dairy Farm Profitability}

Experts rank profitability as an essential factor in sustainability of dairy farms (van Calker et al., 2005). Profitability of dairy farms is influenced primarily by value of milk in the marketplace, cost of feed, and average fixed cost per cow or unit of milk sold.

Feed represents the greatest cost of producing milk. Locally or regionally produced non-commodity feeds, such as pastures and forages, are influenced mostly by growing conditions that influence crop yields. Commodity feeds such as maize or palm kernel reflect global commodity prices. Profitability of the smallest and largest dairy farms are affected similarly by feed prices. Larger farms spread their fixed costs over more units of milk, so scale gives larger farms an advantage in profitability if milk and feed prices are similar among farms.

Although scale of production influences profitability because fixed costs are distributed over more units (kilograms or liters) of milk, small farms with fewer than 10 cows can be profitable because of unpaid family labor and negligible investments in facilities (Hemme and Otte, 2010). As herd size increases, unpaid family labor may keep farms profitable to an extent, but scale generally overrides family labor advantages when herds exceed 50 cows (MacDonald and Newton, 2014). Larger herds are more likely to produce higher quality milk when evaluated by somatic cells and bacteria (Ingham et al., 2011).

A national study of 922 Irish dairy farms during 2012 revealed that profit (financial margin) was related positively with milk output per cow, milk output per hectare, and length of the grazing season (O'Brien et al., 2015). Farms with greatest financial margins also had lowest greenhouse gas (GHG) output per liter of milk leaving the farm.

Most milk is valued as a commodity, including situations where household farmers sell surplus milk on local spot markets. As a commodity, prices paid to farmers for milk change quickly when global demand and supply are imbalanced. Specialty milks (e.g., organic, grass-fed, local, A2A2) are priced according to supply and demand within their niche.

Profitability will continue to be influenced strongly by the balance between global milk supply and demand, because dairy farmers increase output quickly when demand increases but reduce output slowly when supply exceeds demand. This led to a 2 -fold difference in inflation-adjusted prices that dairy farmers in New Zealand were paid for milk solids during the last 20

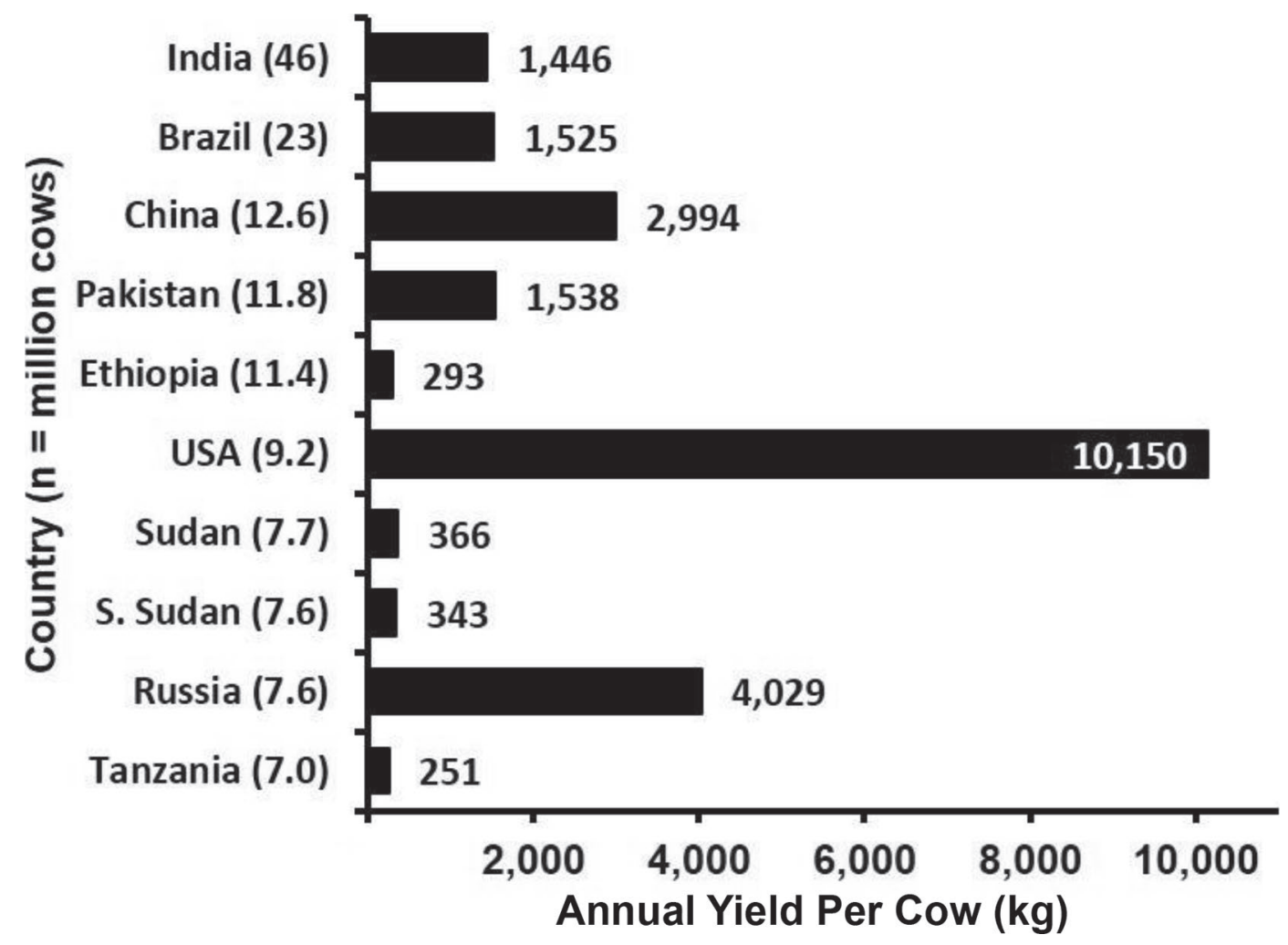

Figure 5. Number of cows (n, millions) and average annual yield $(\mathrm{kg})$ per cow for the 10 countries with the greatest number of milk cows in the FAO database for 2014 (http://www.fao.org/faostat/en/\#home). These countries comprise 150 million milk cows, about 46\% of the world's inventory. 


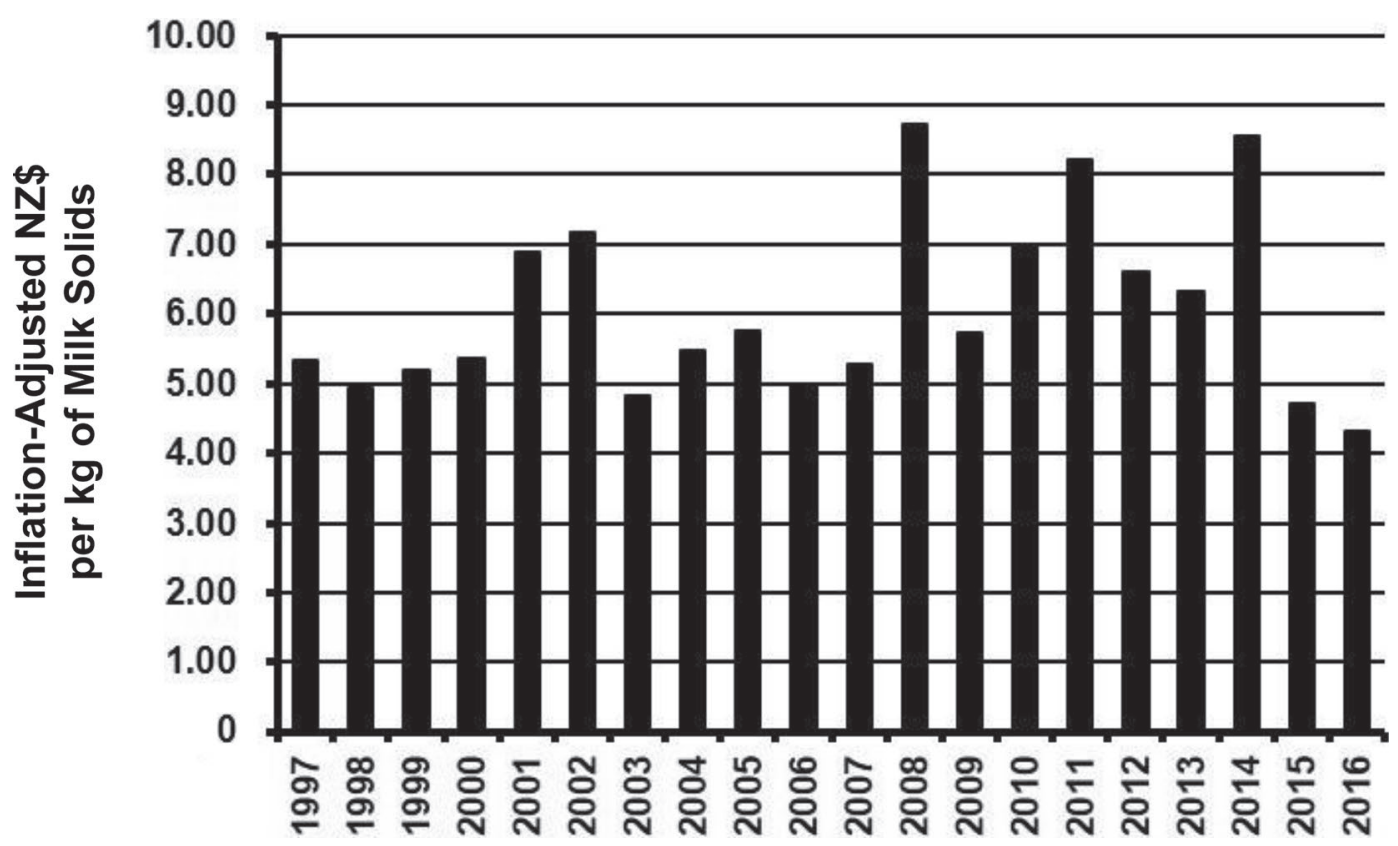

Figure 6. Volatility in inflation-adjusted prices paid to dairy farmers in New Zealand during the last 20 yr. Over this 20 -yr span, NZ $\$ 1$ was equivalent to $\$ 0.62$. Adapted from NZ Dairy Statistics 2015-2016 (Dairy NZ, 2016).

yr (Figure 6). During this period, the amount paid (inflation-adjusted $\mathrm{NZ} \$ / \mathrm{kg}$ of milk solids) ranged from $\mathrm{NZ} \$ 4.30$ to NZ\$8.72 (over this $20-\mathrm{yr}$ span, $\mathrm{NZ} \$ 1$ was equivalent to $\$ 0.62$ ). This volatility in prices paid to farmers for milk inevitably drives less profitable farms out of business. Practices such as supply management limit the effect of lower prices in some countries, but global trade agreements are gradually dampening such practices.

\section{Challenges for Exporters}

Today's major dairy exporting countries are in Europe, North America, and Oceania (Figure 7). Asian and African countries export small percentages of production (inset, Figure 7). Globally, milk processing is dominated by multinational companies, with 10 being headquartered in Europe, 6 in North America, 2 in China, and 1 each in Japan and New Zealand (Rabobank, 2017). Thus, 16 of the top 20 dairy processing companies are headquartered in major exporting regions. These processing companies have facilities scattered across the globe and control much of the tradable dairy products in global commerce.

These exporting regions and associated companies are positioned to meet a significant portion of growth in future demand for dairy products, primarily because they have capacities to produce more milk and to process it into exportable products, and their domestic populations are growing slowly or declining. These regions also have the lowest GHG output per unit of milk leaving the farm gate (Opio et al., 2013). The GHG outputs ( $\mathrm{kg}$ of $\mathrm{CO}_{2}$ equivalents/ $\mathrm{kg}$ of fat- and protein-corrected milk) range from about 1.3 for North America, Eastern and Western Europe, Russia, and Oceania to 7.4 for sub-Saharan Africa. Among 10 countries with the greatest number of dairy cows today, 6 are in regions with the greatest GHG output per unit of milk (Figure 5).

A challenge for dairy exporting countries and regions will be to develop products that provide affordable dairy-based nutrients to meet the needs of children and adults in countries in which demand will exceed local or regional supply. Meeting this need will require a different strategy than is common practice, where components not consumed within domestic and regional markets are exported. For example, in 2016, the United States exported about $4 \%$ of its milk equivalents expressed on a milk-fat basis, and about $17 \%$ expressed on a skim-milk basis, illustrating that domestic supply of milk fat was close to domestic demand, whereas other components such as lactose were in oversupply. In the future, importing countries will seek products that are designed for their specific tastes and customs, so there will be a shift away from shipping surpluses to shipping value-added products for consumers in targeted nations.

It will be necessary to assess current and projected population pyramids in countries to develop age-specific products for export. For example, projections show 
that $31 \%$ of the population in Nigeria in 2067 will be less than 15 yr of age compared with $17 \%$ in the United States. In contrast, $24 \%$ of the population in the United States will be 65 yr or older compared with only $5 \%$ in Nigeria (De Wulf, 2016). Thus, population demographics of exporting countries may differ substantially from demographics of export markets, and this difference will drive the need for country-specific export products (Odle et al., 2017).

Countries with greater current production levels per cow could meet much of the increased demand for dairy products without doubling production per cow. Fifteen of the 20 countries that rank highest in total annual production of milk from dairy cows are located outside Africa and Asia and in regions where growth of populations will be modest or negative during the next $50 \mathrm{yr}$ (Figure 8). Many of these countries are positioned to capitalize on the growing worldwide demand for dairy products.

The circles that are shaded other than white or black in Figure 8 are countries that we identified as having the greatest potential to increase production of milk for export during the next $50 \mathrm{yr}$. These countries have sufficient arable land to produce livestock feed, have farming areas that will be affected relatively less by climate change, have populations that will not increase in size at the rate of fastest-growing regions, and have dairy farming and processing infrastructures that can increase in scale and adopt emerging technologies comfortably. Countries like Russia and Canada have sufficient arable land and water resources to easily double milk production over the next 5 decades. Russia has announced a program to build 800 new 3,000-cow dairy farms within the next few years (Vorotnikov, 2017).

\section{COWS AND HERDS OF THE FUTURE}

In this section, we shift the emphasis to cows, herds, and practices in the world's most developed dairy sectors. It is our belief that technology and practices move from earliest innovators to the rest of their specific sectors, and this will continue to occur in the global dairy industry.

Dairy cows of the future will be more robust with improved health and longevity, driven principally by improvements in genomic selection schemes in developed and developing countries. Welfare of dairy cattle will continue to receive increased attention, and dairy farm facilities will be modified to improve welfare of animals. Dairy farms will become more automated and will uti-

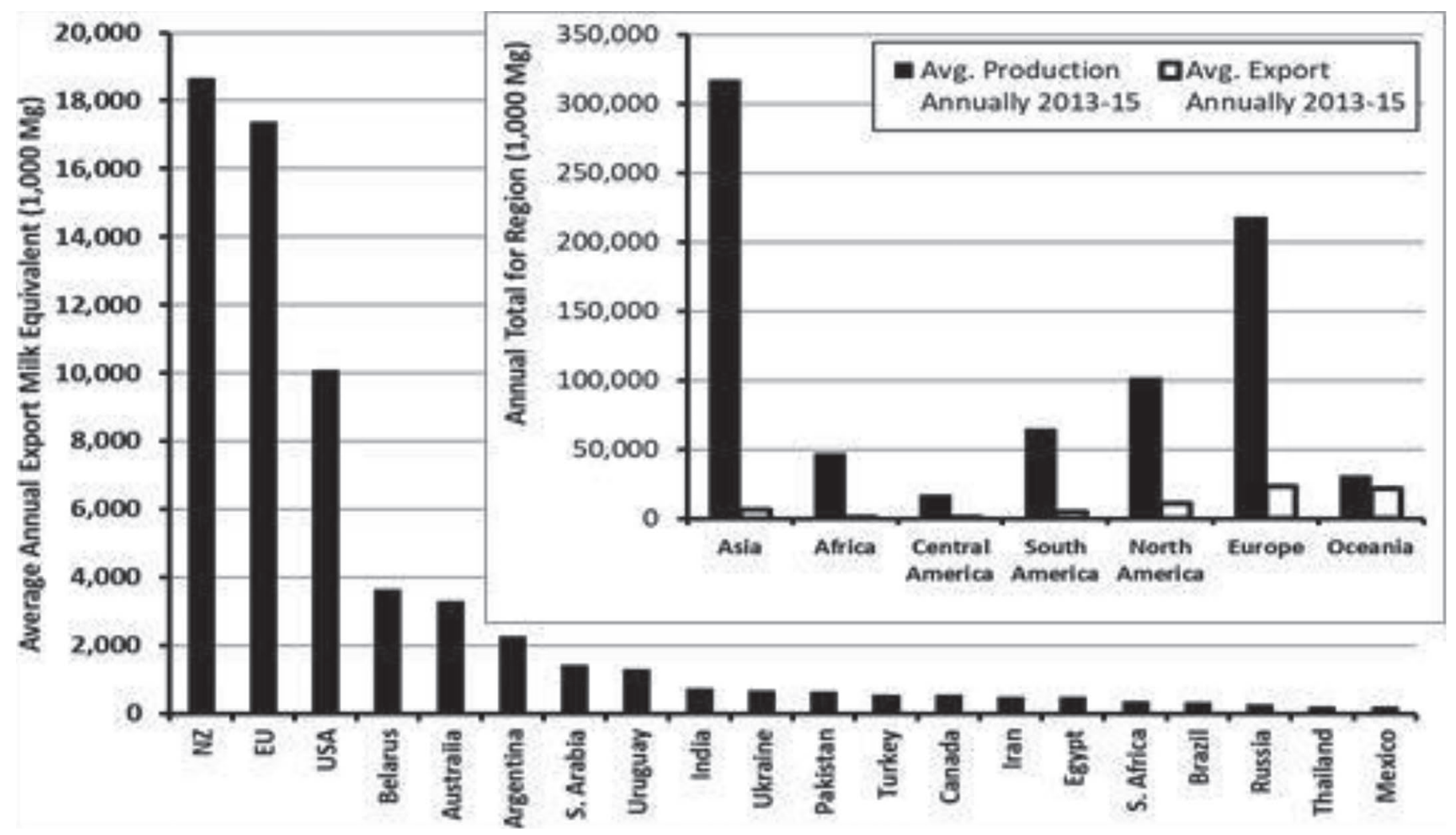

Figure 7. Average annual exports from 2013 to 2015 of milk (milk equivalent basis) from the top 20 exporting countries or regions. Inset shows average (Avg.) annual production and exports for regions of the world, based on data from FAO (2017). 


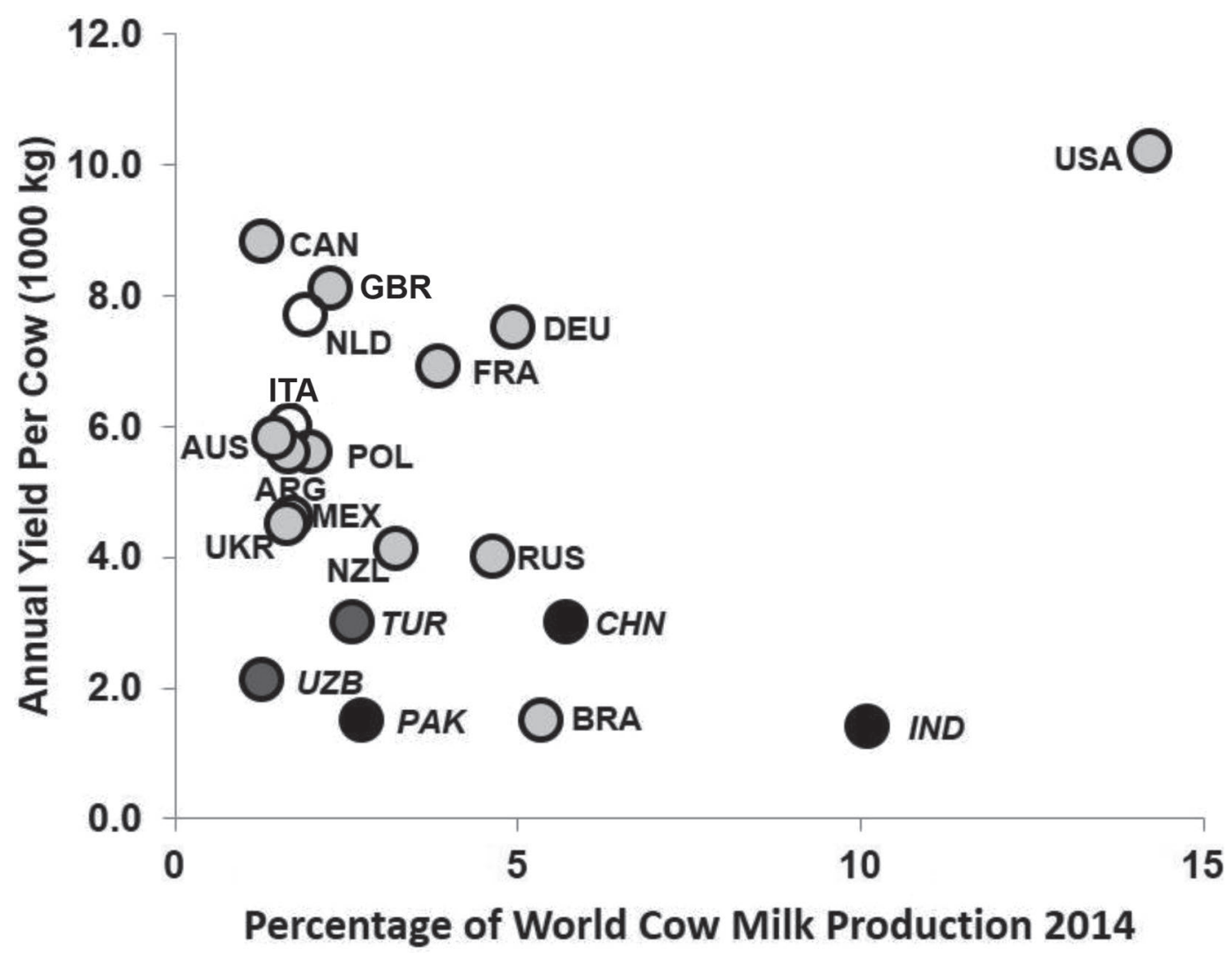

Figure 8. Annual yield of milk per cow and percentage of world's cow milk produced by the top 20 producing countries in 2014 . These countries produced $74.4 \%$ of world's cow milk. Closed (black or dark gray) circles represent countries in Africa or Asia. Circles with either light gray or dark gray shading in their centers are countries that we predict will have the greatest opportunity to export dairy products in 2067 . ARG $=$ Argentina, AUS = Australia, BRA = Brazil, CAN = Canada, CHN = China, DEU = Germany, FRA $=$ France, IND $=$ India, ITA $=$ Italy, MEX $=$ Mexico, NLD $=$ the Netherlands, NZL $=$ New Zealand, PAK $=$ Pakistan, $\mathrm{POL}=$ Poland, RUS $=$ Russia, TUR $=$ Turkey, GBR $=$ Great Britain, UKR $=$ Ukraine, USA = United States, UZB = Uzbekistan (country codes are from http://www.fao.org/countryprofiles/iso3list/en/).

lize sensors and technologies to improve sustainability, particularly associated with soil and crop health, water quality, and emissions. Lateral and vertical integration in the dairy farming sector will lead to more specialization in managing cattle of different ages and stages of production. The number of dairy farms will decline and herd sizes will increase; however, the total number of dairy cows will drop as production per cow climbs in developing countries.

\section{Milk Production of Dairy Cows in the Future}

We project that milk volume and solids produced per cow will climb at an accelerated rate, driven by genomic selection and improvements in quality and digestibility of feedstuffs.

We project that annual milk or milk solids yields for dairy cows in the United States and New Zealand (NZ) will double by 2067 (Figure 9). For these projections, we fit linear and exponential curves to historical US milk yield and NZ milk solids yield data. Within country, linear and exponential fits were essentially identical (US: linear $\mathrm{R}^{2}=0.9896$ and exponential $\mathrm{R}^{2}=$ 0.9868; NZ: linear $\mathrm{R}^{2}=0.8484$ and exponential $\mathrm{R}^{2}=$ $0.8415)$. We discussed the trend lines and opined that average annual milk solids yield would double in $50 \mathrm{yr}$, reaching about midway between linear and exponential extrapolations. A rate higher than the linear extrapolation is justified on the basis that genomic selection has accelerated the rate of genetic progress more recently. Milk volume will continue to rise due to its correlated response to higher solids yield, but it is less likely to double because most market signals will continue to favor milk solids over milk yield.

Dairy production systems in the United States and New Zealand differ in breed composition and how cows are fed and managed. Dairy farms in the United States are smaller than those in New Zealand and typically depend more on stored feed, including concentrates from grains and oilseeds. Dairy farms in New Zealand typically depend on intensive grazing for feed, with less reliance on stored feeds. The formulas for payments to 


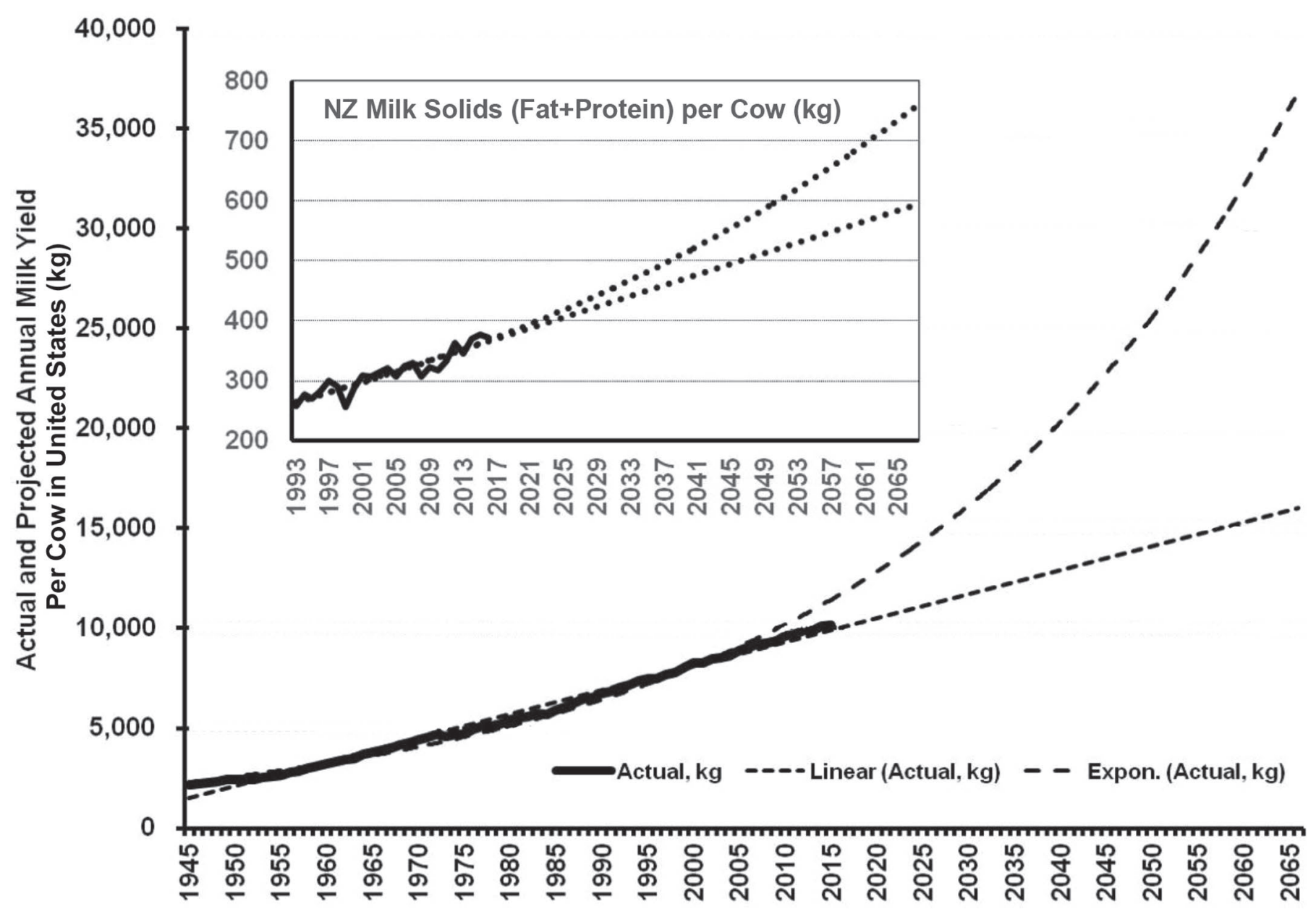

Figure 9. Forecasted change in milk yield of US dairy cows and milk solids of New Zealand (NZ) dairy cows (inset) during the next 50 years. Actual data from multiple USDA sources and NZ Dairy Statistics 2015-2016 (Dairy NZ, 2016) (heavy black lines) were extended through linear and exponential (Expon.) trend lines using Excel (Microsoft Corp., Redmond, WA). We discussed these trend lines and agreed on likely levels of production.

dairy farmers for milk produced differ between the 2 countries. Nevertheless, trends in increased output per cow during the past and forecasts for the future are similar, indicating that dairying in developed countries is following similar paths in improvements of output per cow.

There will be greater emphasis in the future on selection for milk solids rather than yield of milk. Selection for more milk solids is consistent with annual commercial disappearance of dairy products, particularly butterfat [see "Commercial disappearance for dairy product categories (monthly and annual)" available at https://www.ers.usda.gov/data-products/dairy-data/]. Global consumption currently favors increased yields of fat and protein within a lower volume of milk. Most genetic selection indices currently place positive emphasis on fat and protein yield with no weight or a negative weight on milk volume.
Yields of milk and milk solids are reported in several different ways worldwide, which makes it difficult to compare cows and regions. We recommend that dairy agencies and organizations worldwide adopt a common method for measuring yield so that various dairying systems can be compared easily. It would be desirable to adopt a global formula that adjusts for differences in fat and protein concentrations in milk and accounts for the high correlations among volume, lactose, and minerals.

Globally, there will be 2 drivers for increased output per cow: (1) greatly improved accuracy of genomic selection for yield and health traits, and (2) modernization of dairy farms in developing countries. Specific lines within major dairy breeds will be developed efficiently through genomic selection to fit various dairy sectors worldwide (Boichard et al., 2015). If major genes that provide greater heat tolerance and enhanced health are 
identified, these genes will be moved within and among breeds by gene editing. Otherwise, genetic and epigenetic markers for such traits will be included in genomic selection indices. Trans-genes or synthetic genes may be added by inserting sequences into existing genomes.

\section{Genetic Changes in Dairy Cattle}

Impact of Genomic Selection. Generation interval for dairy cattle will continue to decline through combined use of genomic selection, in vitro fertilization (IVF), and other advanced reproductive technologies (Humblot et al., 2010; Pryce et al., 2012; Weller et al., 2017; Cole and VanRaden, 2018). After the first genomic summary was published for US Holstein cattle in 2009, the rate of genetic progress for several traits in Holsteins accelerated (García-Ruiz et al., 2016). Rate of genetic progress per year for yield traits increased by about $50 \%$, but progress increased 3 - to 4 -fold per year for health and longevity traits. In the future, more phenotypes will be added to the list of traits that will be estimated by genomic evaluations, thus accelerating genetic progress to improve animal health and welfare, feed efficiency and excretion of pollutants such as methane. In the past, it has been challenging to incorporate such phenotypes into classical quantitative selection schemes, but with genomic markers for these traits, it is becoming simpler (Boichard et al., 2015; Cole and VanRaden, 2018).

Genetic progress also will benefit from the reduction in generation interval associated with genomic testing and use of reproductive technologies. Since 2009, the generation interval for bulls entering AI in the United States has dropped from approximately 7 to $2.5 \mathrm{yr}$ (García-Ruiz et al., 2016). This interval is approaching the theoretical limit for nonsurgical approaches in which oocytes can be retrieved and sperm recovered at about $8 \mathrm{mo}$ of age in well-fed dairy heifers and bulls (Byrne et al., 2017), producing a generation interval of 17 mo. Generation interval could be dramatically less by 2067 through reproductive innovation. Production of viable oocytes from embryonic stem cells has been demonstrated in mice (Hayashi et al., 2017). This could allow genomically tested embryos to be used as parents and reduce the generation interval to $<1 \mathrm{yr}$, but such techniques have not yet been developed for cattle.

During the next $50 \mathrm{yr}$, use of genomic selection will spread rapidly among breeds that are underrepresented in current world dairy genomic databases (Boichard et al., 2015). Genomic predictions for these breeds are not used currently because of limited data and poor reliability across breeds. Our ability to estimate SNP associations from mixed and crossbred populations will improve and allow a small amount of phenotypic data from an underrepresented breed to be supplemented by large phenotypic databases from major breeds to build more robust databases for breeds worldwide (Hozé et al., 2014).

Genetic Improvement of Health, Welfare, Feed Efficiency, and Methane Excretion. Selection for health- and environmental-related traits will expand as new genomic selection indices are added (Cole and VanRaden, 2018). Existing bovine genes or alleles that benefit cattle exposed to rising temperatures may be moved among breeds by gene editing. For example, a Holstein line that was developed through conventional breeding has a gene for heat tolerance (SLICK gene), and cows in this line show better tolerance to heat stress (Dikmen et al., 2014). Gene editing could be used to quickly move this SLICK gene into other lines or breeds.

Genomic selection will expand in areas related to immunity, disease resistance, reproduction, and mastitis (Thompson-Crispi et al., 2012; Miglior et al., 2014; Parker Gaddis et al., 2014). Holsteins with greater immunity identified by a patented genomic test that measures cell- and antibody-mediated immune responses show stronger immunity and have longer herd life and better reproductive performance (ThompsonCrispi et al., 2012). Genetic markers for antibody- and cell-mediated immune responses have been identified in Holstein cows and bulls, and semen is available for sires that have these greater immune responses (ThompsonCrispi et al., 2014).

Metabolic stress in transition cows is associated with loss of BW and increased metabolic diseases, lameness, and infertility; however, 2 recent studies provide evidence that we can select cows that are more metabolically robust during early lactation. Zachut and Moallem (2017) found that relative postpartum BW loss in Holstein cows differed and was repeatable during the first 5 lactations. Cows that exhibited less BW loss produced the same amount of milk during lactation as those that lost more BW, but those with lower BW loss had better fertility. Ha et al. (2017) identified a genetic component to estimate metabolic change during early lactation in Brown Swiss cows. Brown Swiss bulls differed in types of daughters that they sired, and daughters that were more metabolically robust had extended functional lifetimes in herds. As genetic markers for these traits are identified, there will be increased emphasis on selecting cows that are affected less by metabolic changes during the postpartum period.

Selection for residual feed intake, which estimates efficiency of utilization of feed by individual animals, improves efficiency of milk and meat production and simultaneously lowers methane produced per unit of milk or meat (Manzanilla-Pech et al., 2016; VanderHaar et 
al., 2016). Selection for residual feed intake alone (feed efficiency) may be antagonistic to health and welfare in terms of metabolic changes that occur (Dechow et al., 2017). Thus, selection for feed efficiency is likely to be part of selection indices that are weighted for influences on various traits. Such indices will differ for cattle in different production conditions around the globe.

One genetic opportunity that has global appeal is development of cattle that are resistant to major infectious foreign diseases such as foot and mouth disease (FMD) and endemic diseases like leptospirosis, infectious bovine rhinotracheitis, and bovine viral diarrhea. These diseases affect cow health and may interfere with international trade. Within 5 decades, some of these diseases might be eliminated through genomic selection and other technologies.

Crossbreeding will continue to be used in commercial dairy herds worldwide, but there may be reductions in crossbreeding as genomic-based selection leads to specialized lines within breeds. Dairy farmers would make crosses among certain lines within a breed to capitalize on heterosis from such crosses.

Proprietary lines of dairy cattle will be developed by commercial businesses that have access to genomic information not in the public domain. These lines will have phenotypes that make them profitable for dairy farmers by production of unique or therapeutic milk products, greatly improved feed efficiencies, or other characteristics. These lines will have intellectual property protection that specifies rules on the sale of breeding stock from farms.

The importance of specialized dairy cattle lines in the future will lead to a change in the way that genetic resources are marketed from breeding companies. The primary product will expand from semen to fresh or frozen embryos that will be produced through cell culture techniques maintained for each line. This will essentially move genetic mating decisions from the farm to the IVF laboratory, but it will also increase greatly the types of products produced by the dairy genetic industry.

\section{Understanding Epigenetic Effects}

Significant improvements will occur in understanding roles and importance of non-DNA-sequence based features of the dairy cattle genome and how these affect gene function in response to environment. Classically, this has been referred to as epigenetics and has largely focused on methylation of DNA or acetylation of histone proteins. We now know that many DNA sequences are transcribed into nontranslated RNAs that regulate gene action without serving as a template for protein synthesis. Thus, the focus of epigenetics has broadened to include additional mechanisms such as transfer of RNA between cells (Macaulay et al., 2016) and regulation of genes by nontranslated RNA (Yang et al., 2017).

Months or years can elapse between environmental events that trigger subsequent responses mediated by epigenetic or epigenetic-like mechanisms. Here, we refer to all such displaced responses as epigenetic effects because of their latent temporal nature (Humblot, 2011; Sinclair et al., 2016). One example of an epigenetic effect is how body condition change from 3 to 5 wk postpartum affects conception rate at 12 wk postpartum. Holstein cows that lost more body condition during 5 wk postpartum had lower fertility at first AI at $83 \mathrm{~d}$ postpartum and this led to the Britt hypothesis (Figure 10) - that postpartum BW loss exerted an adverse effect on the developing follicle or its oocyte (Britt, 1992). A subsequent experiment with 1,887 Holstein cows found that cows gaining body condition until 3 wk postpartum had a timed-AI pregnancy rate of $84 \%$ compared with 38 and $25 \%$ for cows that maintained or lost body condition, respectively (Carvalho et al., 2014). This delayed fertility response illustrates the time lag between an event (loss of body condition) and its outcome (conception rate). The specific mechanism for this effect is still unclear, but it is characteristic of an epigenetic effect because the affected oocytes are fertilized but then die during the first few days of development. Lucy et al. (2014) suggested that effects described by the Britt hypothesis should be extended to the oviduct and uterus because of their responses to BW loss during the postpartum period.

Numerous examples of such latent responses exist in dairy cattle. Heifer calves that gain more weight during the first 2 mo of life produce more milk in their first lactation about 2 yr later (Soberon et al., 2012), apparently because more gain in early life induces growth of more mammary epithelial cells that later produce more milk (Soberon and Van Amburgh, 2017). Holstein cows milked more frequently each day during the first 3 to 6 wk postpartum and then at a lower frequency during the remainder of lactation produce more milk during the remainder of lactation than control cows milked at the lower frequency throughout the entire lactation (Bar-Peled et al., 1995; Hale et al., 2003).

We are beginning to understand how cause-andeffect relationships separated by months or years and mediated by genetic or epigenetic mechanisms may be managed beneficially. For example, the ovarian follicle reserve is established during fetal development, and cattle with an optimal ovarian reserve have better reproductive performance (Mossa et al., 2012; JimenezKrassel et al., 2017). Husbandry practices, disease, and environmental conditions can affect this reserve. Restricting weight gain in early gestation in pregnant 


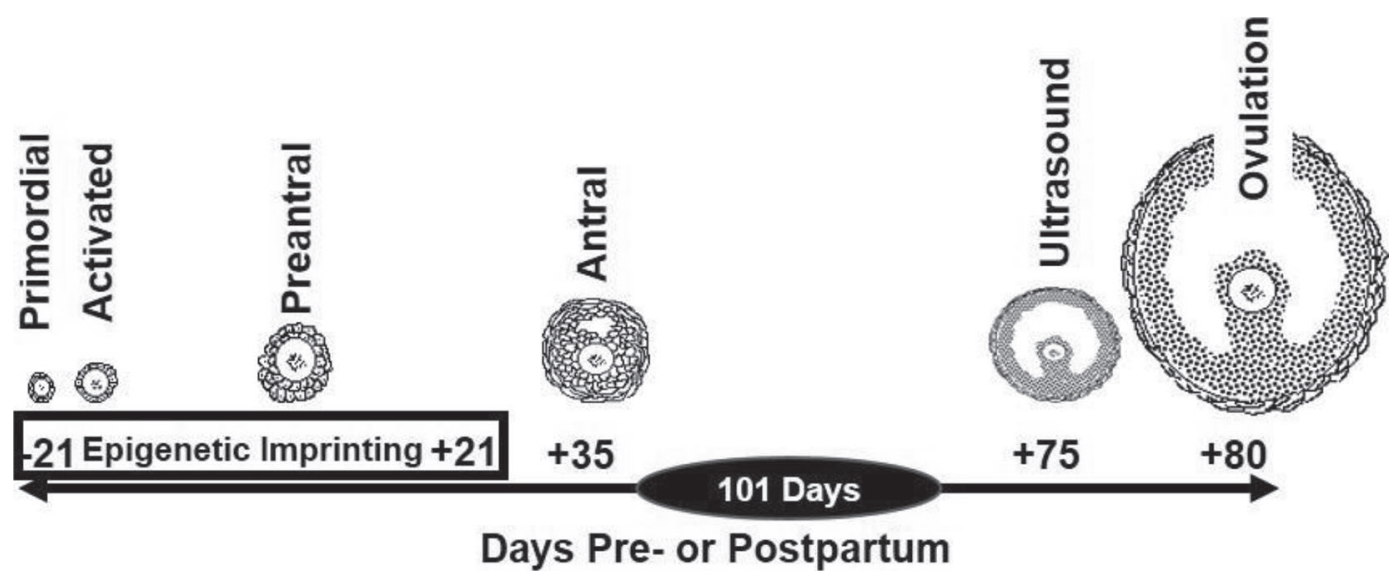

Figure 10. Example of an epigenetic-type effect on the developing bovine oocyte that is subjected to changes in energy balance and other adverse environmental conditions during the transition period in dairy cows. The oocyte is activated about $21 \mathrm{~d}$ prepartum and ovulated about $80 \mathrm{~d}$ postpartum. It is affected by adverse metabolic or disease conditions during the transition period that subsequently affect its survival after fertilization. Model developed based on Britt (1992) and Carvalho et al. (2014).

cows reduces the number of antral follicles in heifers born to those restricted dams (Mossa et al., 2013). Reducing rate of gain during a few weeks before expected puberty increases the number of primordial follicles near first breeding (Freetly et al., 2014; Amundson et al., 2015). Inflammation associated with disease reduces the number of primordial follicles (Bromfield and Sheldon, 2013). Such latent effects will become important targets for management during the next $50 \mathrm{yr}$.

Genomics in the future will expand to cover these and other traits and will include some RNA sequencing and DNA methylation profiling as part of an animal's genomic evaluation. Connecting the dots on some of these pathways and relationships will make it more feasible to incorporate the epigenome into genomic selection.

\section{Genomes of the Microbiota}

Advances in DNA and RNA sequencing technologies are leading to rapid advances in identifying and understanding microbiomes (genomes) of organisms in cattle fed and managed under various conditions (Deusch et al., 2014). Fecal microbiomes of beef cattle differ among cattle receiving different rations within a location, among specific locations within a region, and among different regions of the United States (Shanks et al., 2011).

Although rumen microbiomes are more alike within locations, differences in populations of rumen microorganisms among cows consuming the same TMR in a herd may cause cows to produce milk that differs in composition. Jami et al. (2014) fed primiparous Holstein cows the same TMR during first lactation but found that the ratio of the 2 dominant phyla of rumen organisms (Firmicutes and Bacteroidetes) ranged from $2: 1$ to $1: 3$, and this ratio was correlated $\left(\mathrm{R}^{2}=0.52\right)$ with milk fat yield. Thus, many questions remain about causes of differences in the gastrointestinal microbiome in cattle and how this affects performance and health.

Uncertainty exists about when the gastrointestinal microbiome is established, but substantial evidence indicates that it begins to be established by $2 \mathrm{~d}$ after birth (Yáñez-Ruiz et al., 2015). Studies with identical human twins found that genetics plays an important role $\left(\mathrm{h}^{2}=0.39\right)$ in twins having common gastrointestinal organisms (van Opstal and Bordenstein, 2015). It may be possible to use genomic selection to manipulate gastrointestinal microbiomes to improve feed utilization and health of dairy cattle.

Microbiomes of mammary (Oikonomou et al., 2014) and urogenital (Santos and Bicalho, 2012) systems differ among healthy and diseased states in dairy cows, but it is unclear exactly how changes in the microbiome are related to a disease state. As we develop systems for routinely monitoring microbiomes in cattle, manipulating the microbiome may become a key aspect of herd management.

\section{Biological Limits}

Scientists, farmers, and consumers often ask whether we are reaching the biological limit in milk production. To address this question, our group examined data from top-yielding cows in the United States. Top individual cow records produced during the last decade were 10 to 14 standard deviation (SD) units greater than the average yield per cow in 2014, indicating that the potential for increased yield is substantial. Similarly, we looked 
at US crop yields and found that top yields for maize and soybeans in 2014 were 7 to 9 SD units greater than average yields (Lobell, 2014). Therefore, imminent biological limits do not seem to be restraining output per cow or per hectare. We recognize that greater variation in climatic conditions, including more extreme precipitation and longer periods of drought, will increase variation in yield, but this climatic variability may also give plant breeders opportunities to find varieties and cultivars that are adaptable to greater climatic variation.

\section{ORGANIZATION AND MANAGEMENT OF DAIRY FARMS OF THE FUTURE}

Dairy farming enterprises of the future will be larger and will use lateral integration to house and manage classes of cattle within enterprises. Robotics, sensors, and automation will replace many manual labor activities and enhance sustainable practices for dairy farms. Crops and feeds will require fewer inputs such as fertilizers and pesticides and will be more digestible. Greater focus will be placed on systematically managing the epigenome and microbiome to enhance animal health and productivity. Facilities for housing dairy cattle will be modified to allow dairy cattle to express natural behaviors. The herd will be managed as a superorganism.

\section{Dairy Farm Sizes and Organization}

Dairy farm enterprises will continue to increase in scale to optimize efficiency and lower cost of producing milk (MacDonald and Newton, 2014). Limits on size may be affected by zoning and environmental regulations, proximity to heavily populated areas, and downstream market restrictions.

Dairy enterprises will move toward specialization in housing and managing various groups of cattle (Figure 11). We refer to this as lateral integration, where farmers share resources and specialize in managing specific animal units. This contrasts with vertical integration, where an integrator owns the animals and provides the feed and the farmer serves as the caretaker. Two key components of such specialization will be shared transition facilities and shared feed centers. Cows in a shared transition facility will be milked 3 to 4 times daily and managed to minimize effects of peripartum transition on health and well-being. Feed centers will harvest and store crops from land occupied by dairy enterprises and other farm land and deliver feeds to various units using driverless, automated equipment. The relative cost of feed will be reduced because of the efficiencies of scale.

The shared resource model (Figure 11) will reduce construction and operating costs because specific milking and housing facilities will be identical, using com-

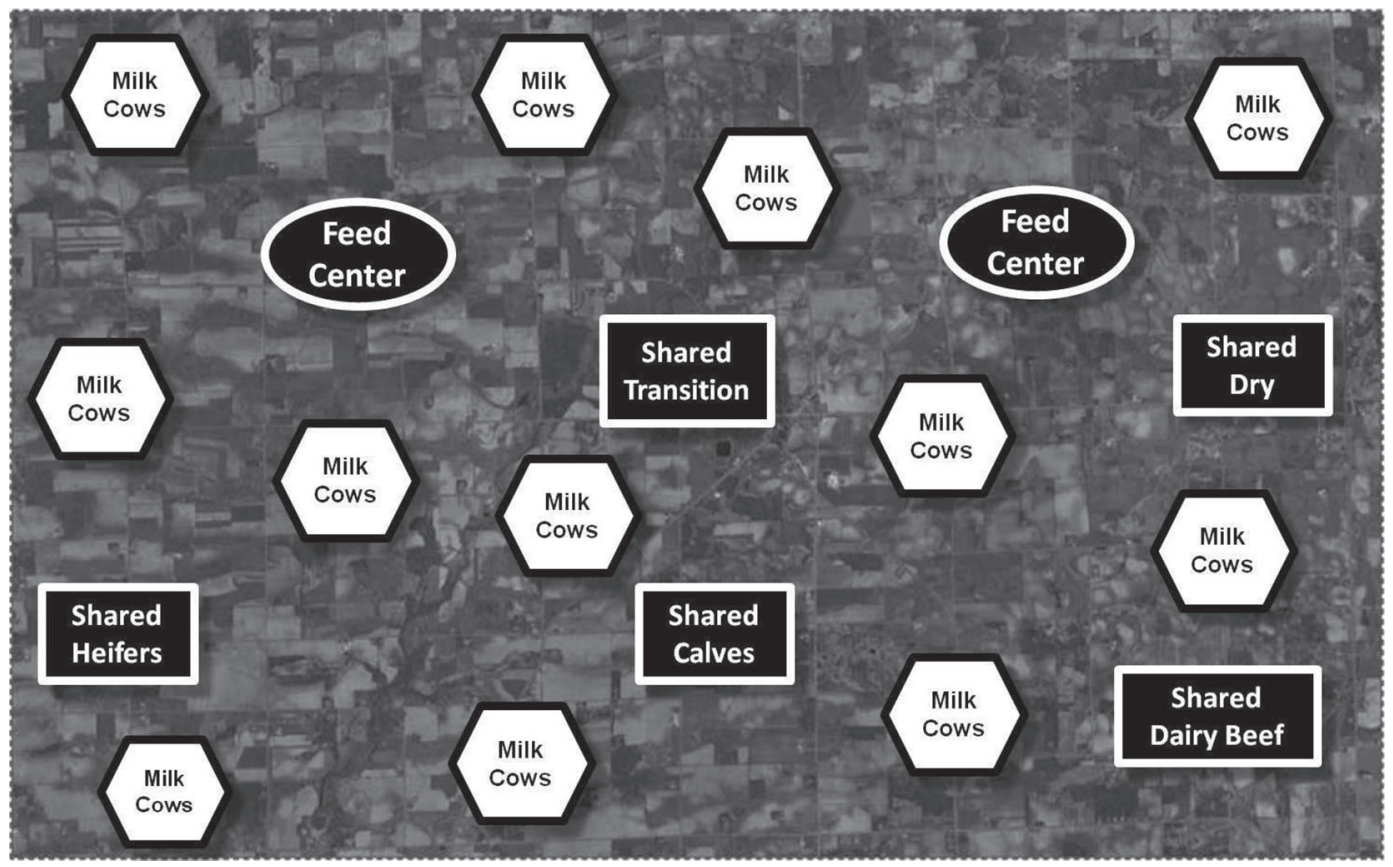

Figure 11. Model of organization of dairy enterprises of the future. Cows will be fed and managed in a transition facility and milked 3 to 4 times per day. Cows will then move to milk cow units for voluntary milking in robotic systems. Calves, heifers, dry cows, and dairy beef will be managed in separate shared facilities. Feed will be stored and mixed in feed centers that serve multiple locations. This organization model would serve a single large dairy enterprise or multiple smaller dairy enterprises. 
mon design and construction. Management protocols and equipment will be standardized among locations within laterally integrated operations. This standardization will permit lactating cows to move easily from one unit to another during different lactations.

Smaller dairy farm enterprises will collaborate and adopt practices of larger enterprises to remain economically competitive. This will eventually lead to vertical integration of smaller units in commercial dairy sectors. Nevertheless, some dairy farms will remain smaller and independent, with targeted niche markets emphasizing grass only milk or local production. Other small farms may produce milk with proprietary therapeutic products.

Dairy beef will increase in importance because its production generates about one-third of the GHG equivalents per unit weight of product compared with traditional beef production (Opio et al., 2013). Cows with lower genomic ranks in herds will be inseminated with sex-selected sperm from beef sires or will receive terminal-cross embryos from beef-breed donors. This will increase the proportion of dairy farm income generated by sale of animals, and these animals may enter a premium consumer market focused on climate-friendly beef products.

\section{Automation and Robotics}

Farms of the future will utilize on-farm and remote sensors, robotics, and automation to improve management of herds, comply with regulations, and reduce the farm's environmental footprint. Data from sensors, robots, and automated equipment will be converted through artificial intelligence to actionable outputs that will inform managers.

Artificial intelligence and machine learning are being used to improve the prediction of complex events such as time of parturition (Borchers et al., 2017). Rapid advances will occur in this area as feedback from sensors, robots, and automated systems is integrated through software that learns and improves prediction or diagnostic accuracy. Sensors monitoring fields where crops are grown and sensors from silos and other feed storage facilities will provide information about digestibility and quality of feed and how this is influenced by field-specific and storage conditions. Added to this sensor information will be data from individual cow intake monitored by 3-dimensional imaging systems. Implantable, biodegradable sensors will monitor mammary gland, liver, and other organs. In-line detectors from each teat cup will monitor teat and udder health, metabolic traits, milk composition, and key hormones. Automated systems will also measure cow BW, body condition, and changes in gait to predict lameness as cows move to and from robots for milking. Milk somatic cell DNA will be monitored to characterize changes in immune and disease status that are reflected in perturbations in key DNA sequences throughout the genome.

Automation and robotics will reduce manual labor on farms. In most developed countries, cows will be milked by robotic systems, and feed will be loaded, mixed, and delivered by driverless vehicles. Energy, soil and crop nutrients, and clean water will be recovered from manure and wastewater on farms through use of anaerobic digesters and specialized osmotic filtration systems. Automation will lead to continued growth in size of dairy farms, because economies of scale will be needed to pay for automated systems. To reduce transportation costs, milk solids will be concentrated on farms, and residual liquid portions containing lactose and some minerals will be re-used in rations. Alternatively, milk with different compositions will be sorted from the cow into tank trucks destined for different milk processing facilities.

\section{Managing "Omics" on the Dairy Farm}

There will be increased focus on practices that benefit animals, crops, soils, and farmsteads by managing microbial populations in a farm's microenvironments and through monitoring and managing epigenetic-mediated effects on animals and crops

Managing the microbiome will depend on a clearer understanding of how it is established and maintained in healthy animals. Knowledge of how feed sources and geographic locations affect microbiomes of dairy cattle will expand quickly and lead to manipulation of the microbiomes in various ways and at different stages of life to improve health, welfare, and productivity.

If current concepts are confirmed, that microbiomes of gastrointestinal, mammary, and urogenital tracts are established before birth or early in life, then products will be developed to inoculate colostrum milk fed to calves at birth to create beneficial microbiomes. Once microbiomes are established, the modification strategy will be to displace or replace specific organisms in a priority order rather than replacing the entire microbiome. Proprietary microbial products will be used therapeutically to replace some antimicrobial products, and these may require a prescription from a veterinarian.

The dairy enterprise will utilize microbial additives for seeds, soils, crops, and irrigation water to improve soil health, boost crop yields, and protect water quality. Seeds will be coated with microbes that enhance soil fertility and improve yields without increasing chemical inputs (Broadfoot, 2016). In housing and milking facilities, microbial mixtures will enhance the quality of bedding materials, increase values of manure and 
wastewater, and improve natural biodiversity of farmsteads.

Epigenetic management will be focused on individual animals and individual fields. For example, cows expected to be exposed to heat stress that raises their body temperature to a critical level may receive certain dietary supplements while being milked robotically or during feeding in dry cow groups. Crops that are expected to be stressed by too much or too little water during specific growing stages will be treated with different inoculants at harvest and storage to improve digestibility or nutrient quality.

\section{Feeds}

Increased focus on improving digestibility of feeds and on utilizing crops that enhance soil fertility and health will improve sustainability of dairy farms. Progress will continue in development of alfalfa and other forages that have less lignin and more starches (Combs, 2016). Grazing systems will become more complex with incorporation of legumes into dairy grazing systems that mostly rely on grasses (Pembleton et al., 2016). Polycultures of grasses that utilize nitrogen more efficiently will emerge and replace grasses that require more nitrogen from chemical fertilizers (Duran et al., 2016. Drought- and salt-tolerant varieties will increase in importance as climate changes and irrigation increases. High-yielding perennial crops, including perennial maize (Murray and Jessup, 2014) and hybrid canes (Głowacka et al., 2016; Burner et al., 2017) that have high sugar contents, will replace annual maize. New feeds or feed supplements will be produced from microalgae (Costa et al., 2016). There will be increased emphasis on reducing amount of chemical fertilizers and pesticides applied to cropland through development of crops that need less fertilization and through broad use of precision farming technologies that match application rates with fertility at square meter-level specificity.

\section{Facilities to Benefit the Cow's Natural Behavior and Health}

Confinement facilities restrict natural behaviors, limit expression of estrus, and contribute to lameness and other health problems that impair well-being of cattle (Dobson and Smith, 2000; von Borell et al., 2007). These effects are attributable largely to cows spending most of their standing or walking time on concrete alleys and walkways rather than on surfaces that provide more cushioning and comfort. Cows learn to behave differently on concrete than on natural surfaces; for example, they display less mounting and standing activity during the same estrus on concrete than on dirt (Britt et al., 1986).

Facilities in the future will be designed and constructed to benefit cows in confinement. Alleys and walkways will be constructed with laminates that combine the underlying strength and durability of concrete with overlying flexible polymers strengthened by carbon materials. Cows may move regularly through covered exercise arenas in their daily routines, and sensors will detect lameness earlier than with today's manual scoring methods. Stall and loose housing facilities will be cleaned, bedded, and managed by robotic equipment to collect waste from bedding surfaces, tend the bedding substrate, and provide fresh material as needed.

Facilities will provide ways for early postpartum cows and newborn calves to interact for an extended period after birth. Most interactions between cows and their calves will be controlled through electronic sorting systems that fit into the natural flow of cows in the facilities.

\section{HERDS AS SUPERORGANISMS}

The term "superorganism" typically refers to a colony of animals, such as bees or termites, that function as a unit (hive or nest) and that has divisions of labor among members of the group (Seeley, 2010). Such groups share sources of food and living conditions and are exposed to the same diseases and environmental conditions. We believe it is beneficial to think of a dairy herd as a superorganism, because the cows within the herd share feed and living conditions and are exposed to environmental conditions and diseases as a group. Studying herds as superorganisms would help us understand why herds located in close proximity with similar climate and feeds may differ quite significantly in performance and health. For example, why did dairy herds in Ireland (O'Brien et al., 2015) differ greatly in yield and profitability during the same grazing season?

A herd is the central production and economic unit of dairy farming, but we lack an understanding of why herds differ in productivity, animal well-being, and economic viability. Historically, animal scientists have practiced reductionist-oriented research, moving from studying complete organisms to studying an organism's systems, organs, cells, and genes. Reductionist research does not provide important data about what accounts for differences among herds.

We need studies focused on herds as experimental units to understand how environment, operational practices, and interactions among animals affect a herd's performance. For example, why do dairy herds located in common physiographic areas and feeding similar diets differ in productivity, health, and animal 
welfare? How is a herd's health and performance affected by land where its feed is grown? What are the most important practices for caring for and managing herds?

Can we understand how cattle in a herd communicate to influence a herd's behavior, health, and productivity? Do cows signal to other cows their responses to personnel, housing conditions, feed, threats, and rewards? How does communication among cows differ among herds? Can we develop ways to communicate effectively with cattle? Many species secrete pheromones, but we are only beginning to identify the signaling chemicals in urine and other excretions of cattle (Archunan and Kumar, 2012). If we could identify and detect volatile or soluble signals in milk, urine, or feces that reflect various physiological or disease states in dairy cattle, this would be a valuable tool for managing herds.

It will be essential to engage scientists from public and private sectors to undertake this task. It will be necessary to develop ways of capturing data that are not collected routinely. For example, what percentage of herds use standard operating protocols for monitoring and recording health and disease events, and how well are these protocols implemented consistently within a herd? Do protocols for the same practices differ among herds? If so, do some protocols result in better outcomes? Are there electronic systems or software that monitor protocols routinely to verify compliance? Artificial intelligence systems used in other sectors will be modified and used to benefit the dairy sector in this area.

We need to look at the entire dairy enterprise when considering the herd as a superorganism. It will take partnerships among dairy farmers, dairy product companies, equipment manufacturers, input suppliers, scientists, veterinarians, and government agencies to conduct such studies. Support will be needed from experts in areas such as operations management, human sciences, and workforce development to understanding how training and recurring improvements in management affect a herd's overall performance.

We currently have more than 40,000 dairy herds in the United States and hundreds of thousands more in other countries, so there are plenty of opportunities to find herds for these studies. It will be important to select several herds within multiple independent areas that reflect differences in weather and climate, typical feedstuffs, types of facilities and housing, and production goals (e.g., conventional, organic, low input, grassfed). In the end, we will learn much about primary factors that influence herd performance, productivity, and health and well-being, and this will be beneficial to feeding the world in 2067.

\section{UNCERTAINTIES}

Dairying has been a part of domestication of livestock for about 360 human generations (Hirst, 2017). The next 50 yr comprise about 2 generations, so it seems unlikely that dairying as we know it will be displaced by 2067 . It is more likely that new technologies coupled with improved sustainability of farming practices will strengthen dairying and keep it positioned to provide dairy foods efficiently and sustainably.

Disruptive industrial technologies could alter dairying. A counterfeit of cow milk is being produced currently through industrial fermentation (http://www .perfectdayfoods.com/). The products being manufactured comprise plant-based sugars and fats, minerals, and proteins secreted by yeast that have been genetically modified by insertion of bovine genes. The challenge for manufacturers will be to produce products that mimic characteristics of cows' milk that make it broadly used in food products worldwide.

Changes in sources of energy could influence where dairy farms are located if energy cost is reduced substantially for desalination of seawater. The multi-national fusion project known as ITER (https://www.iter.org/ proj/inafewlines) and now underway in France could provide a way for clean energy to be produced at a low cost. This could benefit dairy farms in coastal regions that are forecast to have inadequate precipitation in the next 5 decades (Figure 4 ).

Societal preferences will continue to influence food production including dairy farming, particularly as future generations become more displaced from ancestral connections to farming. Many concerns of consumers are focused on practices that they perceive to be unnatural, including confining cattle, overuse of pharmaceuticals, weaning calves shortly after birth, overuse of chemical fertilizers and pesticides, and contamination of streams and sub-surface water with livestock waste. Many of the practices that will be developed and implemented in the next $50 \mathrm{yr}$ will ameliorate several of these issues and dampen concerns of consumers. There will be more zoning- and regulatory-based restrictions on farming, but demographic shifts to urban areas could also free up land resources for farming. Structural consolidation of dairy farming will continue, and the industry will become more vertically integrated than today.

\section{CONCLUSIONS}

The world faces a challenge in feeding its expanding population during the next $50 \mathrm{yr}$, and we forecast that dairying will meet this challenge by exploiting knowledge and technology to develop better dairy cows and 
more productive and sustainable dairy farms. Discoveries and application of new practices in areas such as genomics, microbiomics, and intelligent systems will be among key avenues for boosting output of milk components from dairy cows and milk output from dairy farms. Our vision is that dairying in the future will reflect sustainable intensification that benefits animals, agroecosystems, and humankind through production of key nutrients for human consumption.

\section{ACKNOWLEDGMENTS}

The authors dedicate this journal article to the memory of Dr. Jenks Swann Britt, who died on January 14, 2018. He was a brother, mentor, or friend to many of us and encouraged us regularly during this endeavor. Jenks Britt was an international leader among bovine practitioners and made a lasting impression on clients, students, and colleagues worldwide. JHB notes that the Department of Animal Science at Michigan State University invited him to present a talk on this topic for the H. Allen and Ann Tucker Endowed Lecture in March 2016. Before that lecture, JHB recruited a group of co-authors to provide feedback and to engage in discussions on this topic, and that collaboration has continued. RAC is an employee of the USDA and this statement is required: USDA is an equal opportunity provider and employer.

\section{REFERENCES}

Alexandratos, N., and J. Bruinsma. 2012. World agriculture towards 2030/2050: The 2012 revision. ESA Working Paper No. 12-03. Food and Agriculture Organization, Rome, Italy. http://www.fao .org/global-perspectives-studies/en/.

Amundson, O. L., T. H. Fountain, E. L. Larimore, B. N. Richardson, A. K. McNeel, E. C. Wright, D. H. Keisler, R. A. Cushman, G. A. Perry, and H. C. Freetly. 2015. Postweaning nutritional programming of ovarian development in beef heifers. J. Anim. Sci. 93:5232-5239. https://doi.org/10.2527/jas.2015-9067.

Archunan, G., and R. K. Kumar. 2012. 1-Iodoundecane, an estrus indicating urinary chemo signal in bovine (Bos taurus). J. Vet. Sci. Technol. 3:4. https://doi.org/10.4172/2157-7579.1000121.

Australia Plus. 2017. The Chinese company giving Australian agribusiness new hope. Accessed November 28, 2017. http://www .australiaplus.com/international/business-matters/the-chinese -company-giving-australian-agribusiness-new-hope/8232738.

Bar-Peled, U., E. Maltz, I. Bruckental, Y. Folman, Y. Kalo, J. Gacitua, A. R. Lehrer, C. H. Knight, B. Robinzon, H. Voet, and H. Tagar. 1995. Relationship between frequent milking or suckling in early lactation and milk production of high-producing dairy cows. J. Dairy Sci. 78:2726-2736. https://doi.org/10.3168/jds.S0022 -0302(95)76903-X.

Boichard, D., V. Ducrocq, and S. Fritz. 2015. Sustainable dairy cattle selection in the genomic era. J. Anim. Breed. Genet. 132:135-143. https://doi.org/10.1111/jbg.12150.

Borchers, M. R., Y. M. Chang, K. L. Proudfoot, B. A. Wadsworth, A. E. Stone, and J. M. Bewley. 2017. Machine-learning-based calving prediction from activity, lying, and ruminating behaviors in dairy cattle. J. Dairy Sci. 100:5664-5674. https://doi.org/10.3168/jds .2016-11526.
Bowen, L., S. Ebrahim, B. De Stavola, A. Ness, S. Kinra, A. Bharathi, D. Prabhakaran, and K. S. Reddy. 2011. Dietary intake and rural-urban migration in India: A cross-sectional study. PLoS One 6:e14822. https://doi.org/10.1371/journal.pone.0014822.

Britt, J. H. 1992. Impacts of early postpartum metabolism on follicular development and fertility. Bov. Pract. 24:39-43.

Britt, J. H., R. G. Scott, J. D. Armstrong, and M. D. Whitacre. 1986. Determinants of estrous behavior in lactating Holstein cows. J. Dairy Sci. 69:2195-2202. https://doi.org/10.3168/jds.S0022 $-0302(86) 80653-1$.

Broadfoot, M. 2016. Microbes added to seeds could boost crop production. Scientific American, January 6, 2016. https://www .scientificamerican.com/article/microbes-added-to-seeds-could -boost-crop-production/\#.

Bromfield, J. J., and I. M. Sheldon. 2013. Lipopolysaccharide reduces the primordial follicle pool in the bovine ovarian cortex ex vivo and in the murine ovary in vivo. Biol. Reprod. 88:1-9. https://doi .org/10.1095/biolreprod.112.106914.

Burner, D. M., A. J. Ashworth, D. H. Pote, J. R. Kiniry, D. P. Belesky, J. H. Houx III, P. Carver, and F. B. Fritschi. 2017. Dualuse bioenergy-livestock feed potential of giant Miscanthus, giant reed, and miscane. Agric. Sci. 8:97-112. https://doi.org/10.4236/ as.2017.81008

Byrne, C. J., S. Fair, A. M. English, C. Urh, H. Sauerwein, M. A. Crowe, P. Lonergan, and D. A. Kenny. 2017. Effect of breed, plane of nutrition and age on growth, scrotal development, metabolite concentrations and on systemic gonadotropin and testosterone concentrations following a $\mathrm{GnRH}$ challenge in young dairy bulls. Theriogenology 96:58-68. https://doi.org/10.1016/j theriogenology.2017.04.002.

Carvalho, P. D., A. H. Souza, M. C. Amundson, K. S. Hackbart, M. J. Fuenzalida, M. M. Herlihy, H. Ayres, A. R. Dresch, L. M. Vieira, J. N. Guenther, R. R. Grummer, P. M. Fricke, R. D. Shaver, and M. C. Wiltbank. 2014. Relationships between fertility and postpartum changes in body condition and body weight in lactating dairy cows. J. Dairy Sci. 97:3666-3683. https://doi.org/10.3168/ jds.2013-7809.

Clark, M., and D. Tilman. 2017. Comparative analysis of environmental impacts of agricultural production systems, agricultural input efficiency, and food choice. Environ. Res. Lett. 12:064016 https:// doi.org/10.1088/1748-9326/aa6cd5.

Cole, J. B., and P. M. VanRaden. 2018. Possibilities in an age of genomics: The future of selection indices. J. Dairy Sci. 101:36863701. https://doi.org/10.3168/jds.2017-13335.

Combs, D. 2016. Defining and re-defining forage quality. 2016 Western Alfalfa and Forage Symposium. Accessed Aug. 11, 2017. http:// alfalfa.ucdavis.edu/+symposium/2016/.

Costa, D. F. A., S. P. Quigley, P. Isherwood, S. R. McLennan, and D. P. Poppi. 2016. Supplementation of cattle fed tropical grasses with microalgae increases microbial protein production and average daily gain. J. Anim. Sci. 94:2047-2058. https://doi.org/10 $.2527 /$ jas.2016-0292.

Dairy NZ. 2016. New Zealand Dairy Statistics 2015-2016. Accessed Dec. 6, 2017. www.dairynz.co.nz/dairystatistics.

Davis, A. M., R. Boles, R. James, D. Sullivan, J. Donnell, D. Swirczynsk, and J. Goetz. 2008. Health behaviors and weight status among urban and rural children. Rural Remote Health 8:810.

De Wulf, M. 2016. Population pyramids of the world from 1950 to 2100. Accessed Jul. 17, 2017. https://www.populationpyramid .net/world $/ 2065 /$.

Dechow, C. D., C. R. Baumrucker, R. M. Bruckmaier, and J. W. Blum. 2017. Blood plasma traits associated with genetic merit for feed utilization in Holstein cows. J. Dairy Sci. 100:8232-8238. https://doi.org/10.3168/jds.2016-12502.

Deusch, S., B. Tilocca, A. Camarinha-Silva, and J. Seifert. 2014. News in livestock research-Use of omics-technologies to study the microbiota in the gastrointestinal tract of farm animals. Comput. Struct. Biotechnol. J. 13:55-63. https://doi.org/10.1016/j.csbj 2014.12.005

Dikmen, S., F. A. Khan, H. J. Huson, T. S. Sonstegard, J. I. Moss, G. E. Dahl, and P. J. Hansen. 2014. The SLICK hair locus derived 
from Senepol cattle confers thermotolerance to intensively managed lactating Holstein cows. J. Dairy Sci. 97:5508-5520. https:// doi.org/10.3168/jds.2014-8087.

Dobson, H., and R. F. Smith. 2000. What is stress, and how does it affect reproduction? Anim. Reprod. Sci. 60-61:743 https://doi.org/ 10.1016/S0378-4320(00)00080-4.

Duran, B. E., L. D. S. Duncan, L. G. Oates, C. J. Kucharik, and R. D. Jackson. 2016. Nitrogen fertilization effects on productivity and nitrogen loss in three grass-based perennial bioenergy cropping systems. PLoS One 11:e0151919. https://doi.org/10.1371/journal pone.0151919.

FAO. 2017. Food outlook: Biannual outlook on global food markets. Food and Agriculture Organization of the United Nations, Rome, Italy. Accessed Dec. 12, 2017. http://www.fao.org/3/a-I8080e.pdf.

FAOSTAT. 2017. Livestock data. Accessed Aug. 11, 2017. http://www .fao.org/faostat/en/\#data/QL.

Freetly, H. C., K. A. Vonnahme, A. K. McNeel, L. E. Camacho, O. L. Amundson, E. D. Forbes, C. A. Lents, and R. A. Cushman. 2014 The consequence of level of nutrition on heifer ovarian and mammary development. J. Anim. Sci. 92:5437-5443. https://doi.org/10 $.2527 /$ jas.2014-8086.

García-Ruiz, A., J. B. Cole, P. M. VanRaden, G. R. Wiggans, F. J Ruiz-Lópeza, and C. P. Van Tassell. 2016. Changes in genetic selection differentials and generation intervals in US Holstein dairy cattle as a result of genomic selection. Proc. Natl. Acad. Sci. USA 113:E3995-E4004. https://doi.org/10.1073/pnas.1519061113.

Gerosa, S., and J. Skoet. 2012. Milk availability: Trends in production and demand and medium-term outlook. ESA Working Paper No. 12-01. Food and Agriculture Organization of the United Nations, Rome, Italy. www.fao.org/economic/esa.

Gill, M., P. Smith, and J. M. Wilkinson. 2010. Mitigating climate change: The role of domestic livestock. Animal 4:323-333. https:// doi.org/10.1017/S1751731109004662.

Głowacka, K., A. Ahmed, S. Sharma, T. Abbott, J. C. Comstock, S. P. Long, and E. J. Sacks. 2016. Can chilling tolerance of C4 photosynthesis in Miscanthus be transferred to sugarcane? Glob. Change Biol. Bioenergy 8:407-418. https://doi.org/10.1111/gcbb.12283.

Ha, N.-T., A. R. Sharifi, J. Heise, M. Schlather, U. Schnyder, J. J. Gross, F. Schmitz-Hsu, R. M. Bruckmaier, and H. Simianer. 2017. A reaction norm sire model to study the effect of metabolic challenge in early lactation on the functional longevity of dairy cows. J. Dairy Sci. 100:3742-3753. https://doi.org/10.3168/jds.2016-12031.

Hale, S. A., A. V. Capuco, and R. A. Erdman. 2003. Milk yield and mammary growth effects due to increased milking frequency during early lactation. J. Dairy Sci. 86:2061-2071. https://doi.org/10 .3168/jds.S0022-0302(03)73795-3.

Hayashi, Y., K. Otsuka, M. Ebinac, K. Igarashie, A. Takehara, M Matsumoto, A. Kanaie, K. Igarashi, T. Soga, and Y. Matsui. 2017. Distinct requirements for energy metabolism in mouse primordial germ cells and their reprogramming to embryonic germ cells. Proc. Natl. Acad. Sci. USA 114:8289-8294. https://doi.org/10.1073/ pnas.1620915114

Hemme T. and J. Otte. 2010. Status of and prospects for smallholder milk production-A global perspective. Food and Agricultural Organization of the United Nations, Rome, Italy. Accessed Dec. 4, 2017. http://www.fao.org/docrep/012/i1522e/i1522e.pdf.

Hirst, K. K. 2017. Dairy farming - The ancient history of producing milk. Accessed Sep. 30, 2017. https://www.thoughtco.com/dairy -farming-ancient-history-171199

Hozé, C., S. Fritz, F. Phocas, D. Boichard, V. Ducrocq, and P. Croiseau. 2014. Efficiency of multi-breed genomic selection for dairy cattle breeds with different sizes of reference population. J. Dairy Sci. 97:3918-3929. https://doi.org/10.3168/jds.2013-7761.

Humblot, P. 2011. Reproductive technologies and epigenetics: Their implications for genomic selection in cattle. Acta Sci. Vet. 39(Suppl. 1):s253-s262.

Humblot, P., D. Le Bourhis, S. Fritz, J. J. Colleau, C. Gonzalez, J. C. Guyader, A. Malafosse, Y. Heyman, Y. Amigues, M. Tissie, and C. Ponsart. 2010. Reproductive technologies and genomic selection in cattle. Vet. Med. Int. 2010:192782. https://doi.org/10.4061/2010/ 192787 .
Ingham, S. C., Y. Hu, and C. Ané. 2011. Comparison of bulk-tank standard plate count and somatic cell count for Wisconsin dairy farms in three size categories. J. Dairy Sci. 94:4237-4241. https:// doi.org/10.3168/jds.2011-4310.

Jami, E., B. A. White, and I. Mizrahi. 2014. Potential role of the bovine rumen microbiome in modulating milk composition and feed efficiency. PLoS One 9:e85423. https://doi.org/10.1371/journal .pone.0085423.

Jimenez-Krassel, F., D. M. Scheetz, L. M. Neuder, J. R. Pursley, and J. J. Ireland. 2017. A single ultrasound determination of $\geq 25$ follicles $>3 \mathrm{~mm}$ in diameter in dairy heifers is predictive of a reduced productive herd life. J. Dairy Sci. 100:5019-5027. https://doi.org/ $10.3168 /$ jds.2016-12277.

Kourous, G. 2011. Major gains in efficiency of livestock systems needed (news article, December 14, 2011). Food and Agriculture Organization of the United Nations, Rome, Italy. http://www.fao.org/ news/story/en/item/116937/icode/.

Lobell, D. B. 2014. Files for "Greater Sensitivity to drought accompanies maize yield increase in the US Midwest." Stanford Digital Repository. http://purl.stanford.edu/tp790js7917.

Lucy, M. C., S. T. Butler, and H. A. Garverick. 2014. Endocrine and metabolic mechanisms linking postpartum glucose with early embryonic and foetal development in dairy cows. Animal 8(Suppl. 1):82-90. https://doi.org/10.1017/S1751731114000482.

Lutz, A. 2012. Map of the day: Pretty much everyone lives in the northern hemisphere. Business Insider. Accessed Sep. 25, 2017. http://www.businessinsider.com/90-of-people-live-in-the-northern -hemisphere-2012-5.

Macaulay, A. D., I. Gilbert, S. Scantland, E. Fournier, F. Ashkar, A Bastien, H. A. S. Saadi, D. Gagné, M.-A. Sirard, É. W. Khandjian, F. J. Richard, P. Hyttel, and C. Robert. 2016. Cumulus cell transcripts transit to the bovine oocyte in preparation for maturation. Biol. Reprod. 94:16. https://doi.org/10.1095/biolreprod.114 .127571.

MacDonald, J. M., and D. Newton. 2014. Milk production continues shifting to large-scale farms. Accessed Aug. 8, 2017. https:// www.ers.usda.gov/amber-waves/2014/december/milk-production -continues-shifting-to-large-scale-farms.

Manzanilla-Pech, C. I. V., Y. De Haas, B. J. Hayes, R. F. Veerkamp, M. Khansefid, K. A. Donoghue, P. F. Arthur, and J. E. Pryce. 2016. Genomewide association study of methane emissions in Angus beef cattle with validation in dairy cattle. J. Anim. Sci 94:4151-4166. https://doi.org/10.2527/jas.2016-0431.

Miglior, F., A. Koeck, J. Jamrozik, F. S. Schenkel, D. F. Kelton, G. J. Kistemaker, and B. J. Van Doormaal. 2014. Index for mastitis resistance and use of BHBA for evaluation of health traits in Canadian Holsteins. Interbull Bull. No. 48. Berlin, Germany. Accessed May 21, 2014. https://journal.interbull.org/index.php/ib/ article/view/1349/1420.

Mossa, F., F. Carter, S. W. Walsh, D. A. Kenny, G. W. Smith, J. L. H Ireland, T. B. Hildebrandt, P. Lonergan, J. J. Ireland, and A. C. O. Evans. 2013. Maternal undernutrition in cows impairs ovarian and cardiovascular systems in their offspring. Biol. Reprod. 88:92. https://doi.org/10.1095/biolreprod.112.107235.

Mossa, F., S. W. Walsh, S. T. Butler, D. P. Berry, F. Carter, P. Lonergan, G. W. Smith, J. J. Ireland, and A. C. Evans. 2012. Low numbers of ovarian follicles $3 \mathrm{~mm}$ in diameter are associated with low fertility in dairy cows. J. Dairy Sci. 95:2355-2361.

Murray, S. C., and R. W. Jessup. 2014. Breeding and genetics of perennial maize: Progress, opportunities and challenges. Pages 103111 in Perennial Crops for Food Security; Proceedings of the FAO Expert Workshop, Rome, Italy. Accessed Aug. 11, 2017. http:// www.fao.org/3/a-i3495e.pdf.

Neven, D., T. Reardon, R. Hernandez, and G. Tembo. 2017. Smallholder farmer participation in modernization of a food systemThe dairy value chain in Zambia. Food and Agriculture Organization of the United Nations, Rome, Italy.

Nicholson, C. F., M. I. Gomez, and O. H. Gao. 2011. The costs of increased localization for a multiple-product food supply chain: Dairy in the United States. Food Policy 36:300-310. https://doi .org/10.1016/j.foodpol.2010.11.028. 
O'Brien, D., T. Hennessy, B. Moran, and L. Shalloo. 2015. Relating the carbon footprint of milk from Irish dairy farms to economic performance. J. Dairy Sci. 98:7394-7407. https://doi.org/10.3168/ jds.2014-9222.

Odle, J., S. K. Jacobi, R. D. Boyd, D. E. Bauman, R. V. Anthony, F. W. Bazer, A. L. Lock, and A. C. Serazin. 2017. The potential impact of animal science research on global maternal and child nutrition and health: A landscape review. Adv. Nutr. 8:362-381. https://doi.org/10.3945/an.116.013896.

Oikonomou, G., M. L. Bicalho, E. Meira, R. E. Rossi, C. Foditsch, V. S. Machado, A. G. V. Teixeira, C. Santisteban, Y. H. Schukken, and R. C. Bicalho. 2014. Microbiota of cow's milk; Distinguishing healthy, sub-clinically and clinically diseased quarters. PLoS One 9:e85904. https://doi.org/10.1371/journal.pone.0085904.

Opio, C., P. Gerber, A. Mottet, A. Falcucci, G. Tempio, M. MacLeod, T. Vellinga, B. Henderson, and H. Steinfeld. 2013. Greenhouse gas emissions from ruminant supply chains-A global life cycle assessment. Food and Agriculture Organization of the United Nations, Rome, Italy. http://www.fao.org/docrep/018/i3461e/i3461e.pdf.

Parker Gaddis, K. L., J. B. Cole, J. S. Clay, and C. Maltecca. 2014. Genomic selection for producer-recorded health event data in US dairy cattle. J. Dairy Sci. 97:3190-3199. https://doi.org/10.3168/ jds.2013-7543.

Pembleton, K. G., J. L. Hills, M. J. Freeman, D. K. McLaren, M. French, and R. P. Rawnsley. 2016. More milk from forage: Milk production, blood metabolites, and forage intake of dairy cows grazing pasture mixtures and spatially adjacent monocultures. J. Dairy Sci. 99:3512-3528. https://doi.org/10.3168/jds.2015-10542.

Peters, C. J., J. Picardy, A. F. Darrouzet-Nardi, J. L. Wilkins, T. S. Griffin, and G. W. Fick. 2016. Carrying capacity of U.S. agricultural land: Ten diet scenarios. Elementa 4:116. https://doi.org/10 .12952/journal.elementa.000116.

Pryce, J. E., B. J. Hayes, and M. E. Goddard. 2012. Novel strategies to minimize progeny inbreeding while maximizing genetic gain using genomic information. J. Dairy Sci. 95:377-388. https://doi.org/10 $.3168 /$ jds.2011-4254.

Rabobank. 2017. Global dairy top 20 2017. Accessed Nov. 28, 2017. https://research.rabobank.com/far/en/sectors/dairy/Dairy-top $-20-2017 . h t m l$.

Roser, M., and H. Ritchie. 2017. Yields and land use in agriculture. https://ourworldindata.org/yields-and-land-use-in-agriculture/.

Roy, S. B., L. Chen, E. H. Girvetz, E. P. Maurer, W. B. Mills, and T. M. Grieb. 2012. Projecting water withdrawal and supply for future decades in the U.S. under climate change scenarios. Environ. Sci. Technol. 46:2545-2556. https://doi.org/10.1021/es2030774.

Santos, T. M. A., and R. C. Bicalho. 2012. Diversity and succession of bacterial communities in the uterine fluid of postpartum metritic, endometritic and healthy dairy cows. PLoS One 7:e53048. https:// doi.org/10.1371/journal.pone.0053048.

Seeley, T. D. 2010. Honeybee Democracy. Princeton University Press, Princeton, NJ.

Shanks, O. C., C. A. Kelty, S. Archibeque, M. Jenkins, R. J. Newton, S. L. McLellan, S. M. Huse, and M. L. Sogin. 2011. Community structures of fecal bacteria in cattle from different animal feeding operations. Appl. Environ. Microbiol. 77:2992-3001. https://doi .org/10.1128/AEM.02988-10.

Sinclair, K. D., K. M. D. Rutherford, J. M. Wallace, J. M. Brameld, R. Stöger, R. Alberio, D. Sweetman, D. S. Gardner, V. E. A. Perry, C. L. Adam, C. J. Ashworth, J. E. Robinson, and C. M. Dwyer. 2016. Epigenetics and developmental programming of welfare and production traits in farm animals. Reprod. Fertil. Dev. 28:14431478. https://doi.org/10.1071/RD16102.
Soberon, F., E. Raffrenato, R. W. Everett, and M. E. Van Amburgh. 2012. Preweaning milk replacer intake and effects on long-term productivity of dairy calves. J. Dairy Sci. 95:783-793. https://doi .org/10.3168/jds.2011-4391.

Soberon, F., and M. E. Van Amburgh. 2017. Effects of preweaning nutrient intake in the developing mammary parenchymal tissue. J. Dairy Sci. 100:4996-5004. https://doi.org/10.3168/jds.2016-11826.

Thompson-Crispi, K. A., M. Sargolzaei, R. Ventura, M. Abo-Ismail, F. Miglior, F. Schenkel, and B. A. Mallard. 2014. A genome-wide association study of immune response traits in Canadian Holstein cattle. BMC Genomics 15:559. https://doi.org/10.1186/1471-2164 $-15-559$.

Thompson-Crispi, K. A., A. Sewalem, F. Miglior, and B. A. Mallard. 2012. Genetic parameters of adaptive immune response traits in Canadian Holsteins. J. Dairy Sci. 95:401-409. https://doi.org/10 $.3168 /$ jds.2011-4452.

United Nations. 2017. Department of Economic and Social Affairs, Population Division (2017). World Population Prospects: The 2017 Revision. Accessed Jul. 19, 2017. https://esa.un.org/unpd/ wpp/Download/Standard/Populations.

van Calker, K. J., P. B. M. Berentsen, G. W. J. Giesen, and R. B. M. Huirne. 2005. Identifying and ranking attributes that determine sustainability in Dutch dairy farming. Agric. Human Values 22:53-63. https://doi.org/10.1007/s10460-004-7230-3.

van Opstal, E. J., and S. R. Bordenstein. 2015. Rethinking heritability of the microbiome. Science 349:1172-1173. https://doi.org/10 .1126/science.aab3958.

VandeHaar, M. J., L. E. Armentano, K. Weigel, D. M. Spurlock, R. J. Tempelman, and R. Veerkamp. 2016. Harnessing the genetics of the modern dairy cow to continue improvements in feed efficiency. J. Dairy Sci. 99:4941-4954. https://doi.org/10.3168/jds 2015-10352

von Borell, E., H. Dobson, and A. Prunier. 2007. Stress, behavior and reproductive performance in female cattle and pigs. Horm. Behav. 52:130-138. https://doi.org/10.1016/j.yhbeh.2007.03.014.

Vorotnikov, V. 2017. Russia invests in building large-sized dairy farms. Dairy Global, May 11, 2017. Accessed Dec. 11, 2017. http:// www.dairyglobal.net/Articles/General/2017/5/Russia-invests-in -building-large-sized-dairy-farms-130360E/.

Weller, J. I., E. Ezra, and M. Ron. 2017. Invited review: A perspective on the future of genomic selection in dairy cattle. J. Dairy Sci. 100:8633-8644. https://doi.org/10.3168/jds.2017-12879.

Wilkinson, J. M. 2011. Re-defining efficiency of feed use by livestock. Animal 5:1014-1022. https://doi.org/10.1017/S175173111100005X.

World Bank. 2017. Arable land (hectares per person). Accessed Nov. 28, 2017. https://data.worldbank.org/indicator/AG.LND.ARBL HA.PC.

Yáñez-Ruiz, D. R., L. Abecia, and C. J. Newbold. 2015. Manipulating rumen microbiome and fermentation through interventions during early life: A review. Front. Microbiol. 6:1133 https://doi.org/10 $.3389 /$ fmicb.2015.01133.

Yang, Y., C. R. Yang, S. J. Han, E. M. Daldello, A. Cho, J. P. S. Martins, G. Xia, and M. Conti. 2017. Maternal mRNAs with distinct 3' UTRs define the temporal pattern of Ccnb1 synthesis during mouse oocyte meiotic maturation. Genes Dev. 31:1302-1307. https://doi.org/10.1101/gad.296871.117.

Zachut, M., and U. Moallem. 2017. Consistent magnitude of postpartum body weight loss within cows across lactations and the relation to reproductive performance. J. Dairy Sci. 100:3143-3154. https://doi.org/10.3168/jds.2016-11750. 